\title{
Perceptions of benefits/problems of part-time employment on the job performance of secondary teachers of agricultural education
}

\author{
Connie McClung Scarbrough \\ West Virginia University
}

Follow this and additional works at: https://researchrepository.wvu.edu/etd

\section{Recommended Citation \\ Scarbrough, Connie McClung, "Perceptions of benefits/problems of part-time employment on the job performance of secondary teachers of agricultural education" (2001). Graduate Theses, Dissertations, and Problem Reports. 1269. \\ https://researchrepository.wvu.edu/etd/1269}

This Thesis is protected by copyright and/or related rights. It has been brought to you by the The Research Repository @WVU with permission from the rights-holder(s). You are free to use this Thesis in any way that is permitted by the copyright and related rights legislation that applies to your use. For other uses you must obtain permission from the rights-holder(s) directly, unless additional rights are indicated by a Creative Commons license in the record and/ or on the work itself. This Thesis has been accepted for inclusion in WVU Graduate Theses, Dissertations, and Problem Reports collection by an authorized administrator of The Research Repository @ WVU. For more information, please contact researchrepository@mail.wvu.edu. 


\title{
Perceptions of Benefits/Problems of Part-time Employment On the Job Performance of Secondary Teachers of Agricultural Education
}

\author{
Connie McClung Scarbrough
}

\author{
Thesis submitted to the \\ College of Agriculture, Forestry and Consumer Sciences \\ at West Virginia University \\ in partial fulfillment of the requirements \\ for the degree of \\ Master of Science \\ in \\ Agricultural Education
Layle D. Lawrence, Ph.D., Co-Chair
Harry N. Boone, Ph.D., Co-Chair
Stacy A. Gartin, Ph.D.
Jean M. Woloshuk, Ed.D.
Division of Resource Management \\ Kerry S. Odell, Ph.D.
}
Morgantown, West Virginia 2001

Keywords: Agricultural Education, Multiple Job Holding, Part-time Employment, Moonlighting 


\begin{abstract}
Perceptions of Benefits/Problems of Part-time Employment On the Job Performance of Secondary Teachers of Agricultural Education
\end{abstract}

\title{
Connie McClung Scarbrough
}

The purpose of the study was to examine the self-perceived potential benefits and/or problems of part-time employment on the job performance of secondary teachers of Agricultural Education. The population consisted of 108 agricultural educators who held teaching positions during the 2000-2001 school year in West Virginia, Ohio, and Kentucky and were employed within a 150-mile radius of Ripley, West Virginia. A descriptive research design was used for the study. There have been no studies conducted as to the number of agricultural educators involved in part-time employment and to what extent they are involved. Many have questioned the feasibility of a teacher performing their duties while moonlighting. A major finding of the research was that there are strong feelings as to the benefits and problems associated with these activities and that over $50 \%$ of agricultural teachers were involved in some kind of part-time employment. Hands-on education has always been a cornerstone of the total agricultural program. Agricultural educators are experiencing benefits, as well as problems, associated with this personal "hands-on" approach to educating students. 
Dedicated to Oscar J. Harris and Michael T. Kubina who were my Agricultural teachers at Ripley High School. The lives you have touched in a positive way are impossible to number. 


\section{ACKNOWLEDGEMENTS}

To the many agricultural education teachers who came through with valuable responses and thought provoking comments, let me offer my heart-felt gratitude. It is you who have made this work possible.

To Dr. Layle Lawrence who I admire and esteem, let me express my endless gratitude. For your challenges to me to complete the project and for focusing on the strengths of this study rather than its numerous weaknesses, I praise your generosity. Thank you for the opportunity to become a teacher in the first place and for those tough evaluations that made me want to be a better teacher. You, by your example, are a great leader, writer, and teacher and we all know there is no better way to teach.

To Dr. Harry Boone, the excellence you bring to the program at West Virginia University at Morgantown is to be exalted. The effort and expertise you bring to the university has been a blessing to me. The tangents, I so easily went off on in my journey to finish, were always countered with your questions leading me back from the brink of failure. Your focus on a problem and its remedy are amazing. Thank you so much for your time and talent that are finally making this possible. Your work with words and numbers is remarkable.

Dr.'s Kerry Odell and Stacy Gartin are the best. You inspire and suggest, council and mentor. Even though you will say you are only doing your job, we in agriculture all know you always go above and beyond the call of duty. You keep us all smiling and there is not enough of that in the world.

To Dr. Jean Woloshuk who agreed to be on my committee and for all your work throughout the year on behalf of the youth of West Virginia. Your efforts are not unnoticed. 
May God bless you for your offer of lodging and for your comments and suggestions that made me look even closer at the findings and conclusions.

To Phyllis McClung (Mom), for all your efforts while I was in school and specifically for your artwork on my survey booklet, let me say, "thanks." You are the sweetest person I know.

To Gerald McClung (Dad), thanks for always challenging me.

Drew Spiker, Matt White, and Jon Spencer deserve a thank you, as well, for asking me, "Did you work on your thesis today?"

To William C. West who never gave up on the fact that I might complete this project, a great big thank you. Remember with this paper, I "shot for the moon". It is finally complete.

I am so thankful each day that Ruth Ann Hutchinson taught me to type.

To my son Daniel who has been a part of my life and my best friend for the last 18 years: Thank you for your sense of humor, the talents you have let me witness, your forgiving nature and your listening ear. You have been my link to the future and a touchstone that I looked to for all aspects of my life. Thank you for help on this and every other project you have helped me to complete. Daniel, you are my best self.

To my husband Michael who is my greatest critic and my closest confidant, your genius has inspired me to pick up where I began twelve years ago and carry this study across the finish line. For picking up the slack at home, for assisting me in my school work, and for licking stamps at 3:00 a.m., I can never repay you but someday God will.

To all my students from Barboursville to Ripley who have given me the honor of being their teacher, may your lives be as blessed as you have made mine over the years. 


\section{TABLE OF CONTENTS}

TITLE PAGE

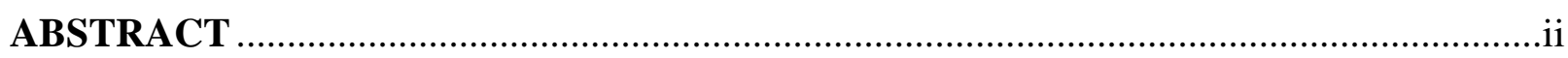

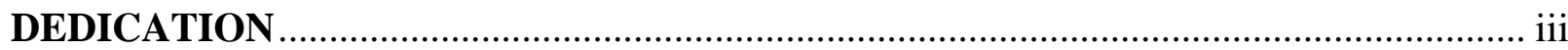

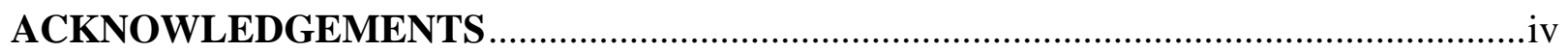

TABLE OF CONTENTS .......................................................................................

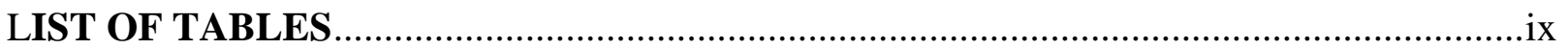

CHAPTER I INTRODUCTION ........................................................................... 1

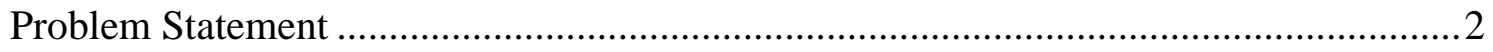

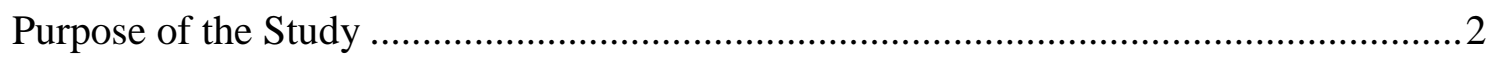

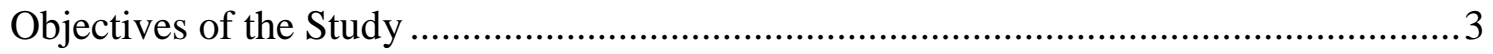

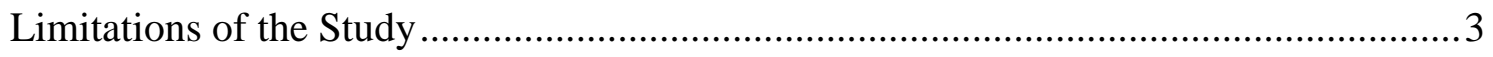

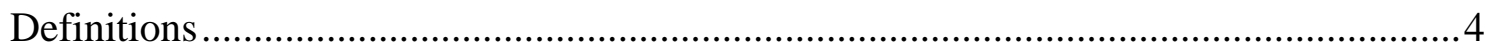

CHAPTER II REVIEW OF LITERATURE .............................................................

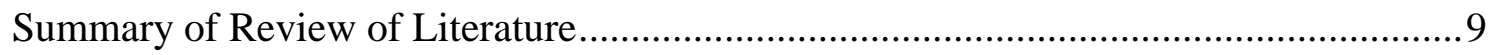

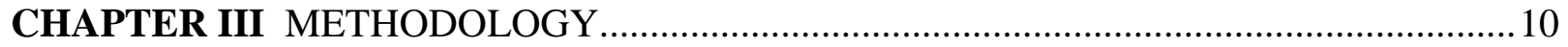

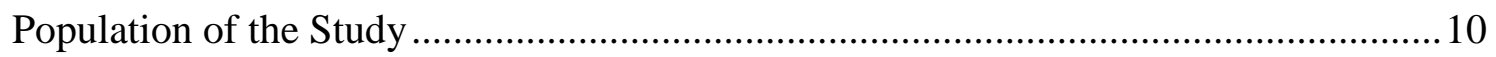

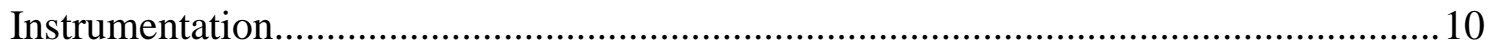

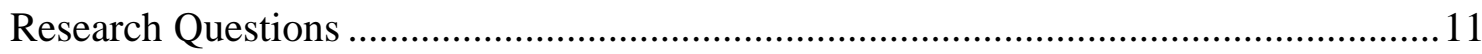

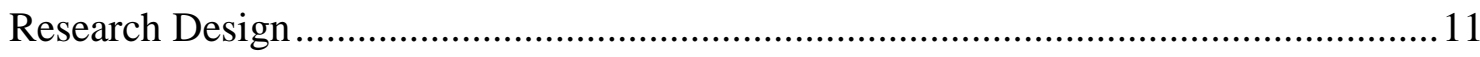

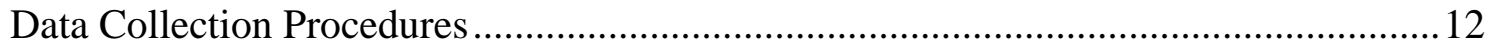

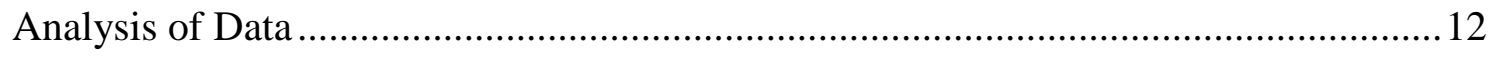

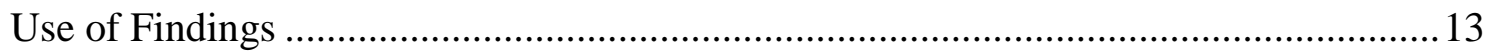




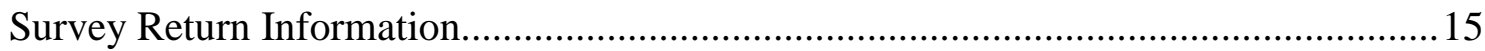

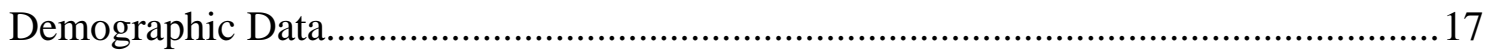

Perceived Benefits and Problems of the Agricultural Education Program which Result from the Teacher's Part-time Employment ..................................................................... 21

Comparison of Perceived Benefits to the Agricultural Education Program Which Result from the Teacher's Part-time Employment by Involvement in Part-time Production

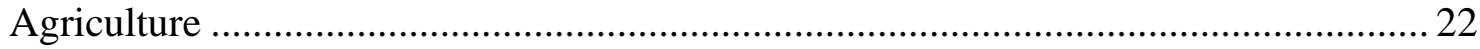

Comparison of Perceived Problems of the Agricultural Education Program which Result from the Teacher's Part-time Employment, According to Involvement in Production Agriculture

Comparison of Perceived Benefits of the Agricultural Education Program which Result from the Teacher's Part-time Employment, According to Involvement in Part-time Agribusiness 26

Comparison of Perceived Problems of the Agricultural Education Program which Result from the Teacher's Part-time Employment, According to Involvement in Part-Time Agribusiness 28

Comparisons of Perceived Benefits to the Agricultural Education Program which Result from the Teacher's Part-time Employment, According to Involvement in Other

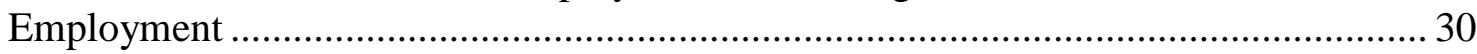

Comparisons of Perceived Problems to the Agricultural Education Program which Result from the Teacher's Part-time Employment, According to Involvement in Other

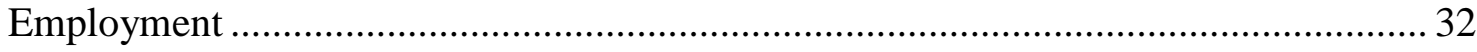

Comparisons of Perceived Benefits and Problems of the Agricultural Education Program which Result from the Teacher's Part-time Employment, According to Teaching

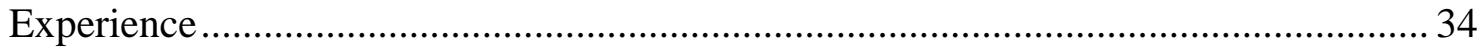

Comparisons of Perceived Benefits/Problems of the Agricultural Education Program which Result from the Teacher's Part-time Employment, According to Length of Teacher Contract 39

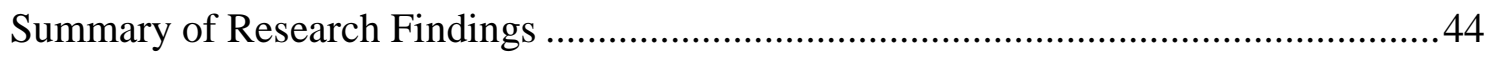

CHAPTER V SUMMARY, CONCLUSIONS AND RECOMMENDATIONS 45 


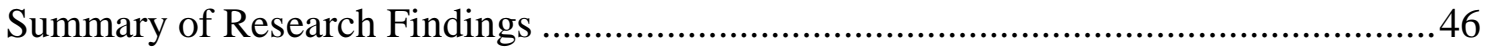

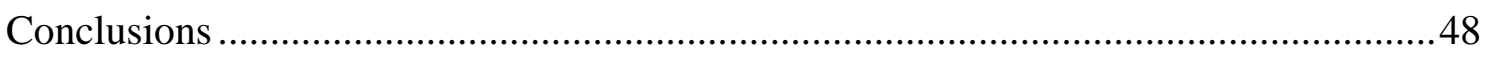

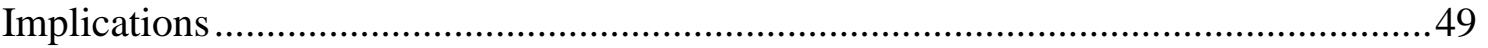

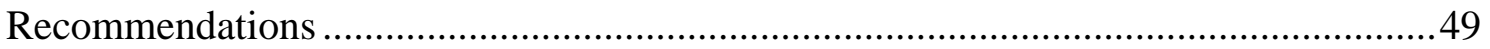

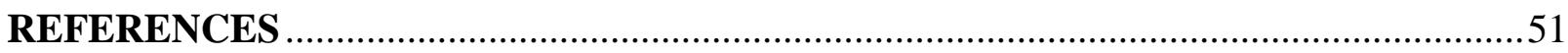

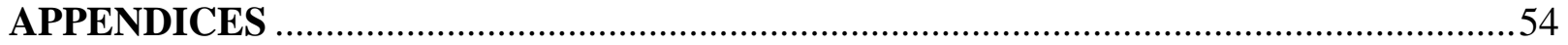

APPENDIX A: Cover Letter to Secondary Agricultural Educators ...............................55

APPENDIX B: Survey Instrument: What is the Appeal of Part-time?...........................57

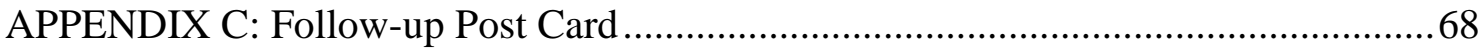

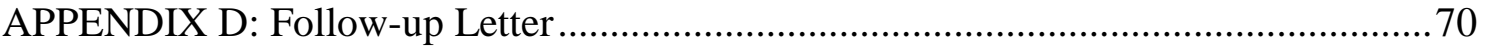

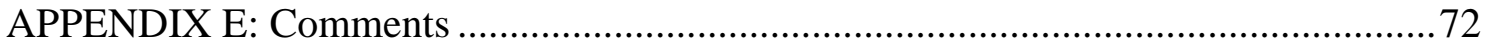

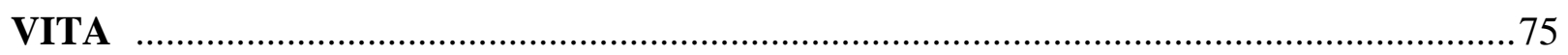




\section{LIST OF TABLES}

Table

Page

1. Number of Surveys or Reminders and Associated Response Rate by State Following Each Phase of Data Collection 16

2. Demographic Characteristics of Respondents Reported by State. 18

3. Demographic Data as it Relates to Involvement in Part-time Employment 20

4. Perceived Benefits to the Agricultural Education Program which Result from the Teacher's Part-time Employment, According to Involvement in Part-time Production Agriculture 23

5. Perceived Problems of the Agricultural Education Program which Result from the Teacher's Part-time employment, According to Involvement in Production Agriculture ... 24

6. Perceived Benefits to the Agricultural Education Program which Result from the Teacher's Part-time Employment, According to Involvement in Part-time Agribusiness .. 27

7. Perceived Problems of the Agricultural Education Program which Result from the Teacher's Part-time employment, According to Involvement in Agribusiness .... 28

8. Perceived Benefits to the Agricultural Education Program which Result from the Teacher's Part-time Employment, According to Involvement in Other Employment Endeavors 31

9. Perceived Problems of the Agricultural Education Program which Result from the Teacher's Part-time employment, According to Involvement in Other Employment Endeavors

10. Perceived Benefits of the Agricultural Education Program which Result From the Teacher's Part-time Employment, According to Years of Teaching Experience

11. Perceived Problems of the Agricultural Education Program which Result From the Teacher's Part-time Employment, According to Years of Teaching Experience 36

12. Perceived Benefits of the Agricultural Education Program which Result From the Teacher's Part-time Employment, According to Teacher Contract....

13. Perceived Problems of the Agricultural Education Program which Result From the Teacher's Part-time Employment, According to Teacher Contract.... 


\section{CHAPTER I}

\section{INTRODUCTION}

The agriculture industry continues to be America's largest employer. Past innovators in the fields of agriculture were cognizant of the importance of this industry in the development and success of the nation and of the need for young people to be trained to fill vacancies in this vital industry.

With the passage of the Smith-Hughes Act in 1917, agricultural education was incorporated into the curricula of secondary public schools for the purpose of establishing students in agriculture or agribusiness. In recent years, agriculture has evolved to include many specialized areas of farming and agribusiness. While the curriculum has changed, the basic elements of the agricultural education program; classroom/laboratory instruction, supervised agricultural experience programs, and FFA, for the most part, have remained the same.

According to Phipps and Osborne (1988) in their Handbook on Agriculture Education in

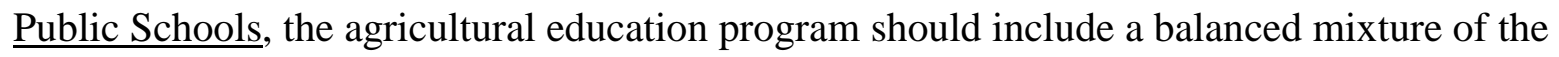
following parts to be successful. It should include classroom activities such as exploration of supervised agricultural experience programs and problem-solving techniques, which will direct students into realistic and profitable production or agribusiness experience programs. The program was designed to allow the teacher to spend time supervising students during initiation of agricultural experience programs and subsequent visits to increase scope and quality.

It is also important, for the agricultural education teacher to allocate time for participation in organizations such as FFA and Young Farmers Associations. In West Virginia, a "total" program of agriculture education includes teaching Young and Adult Farmer courses throughout the year. 
The job of the agricultural educator includes a variety of activities, and much time must be given to the satisfactory completion of these designated elements of the program. Teachers, teacher educators, state supervisors, and even administrators have questioned the feasibility of an agricultural educator performing his/her teaching responsibilities, as well as engaging in parttime farming and/or agribusiness enterprises.

\section{$\underline{\text { Problem Statement }}$}

Because teacher educators, state supervisors, administrators, and to some degree, the general public perceive teaching secondary school agricultural education as a full-time profession, it is important to establish the degree to which agricultural education teachers are engaged in part-time employment activities. In addition to the level of involvement in part-time employment, it is important to establish their perceptions of the benefits and problems associated with these activities. A review of literature failed to produce research on the number of high school agricultural educators involved in part-time employment in West Virginia, Ohio, and Kentucky. Through association with peers, the researcher has developed some personal opinions on the level of involvement and teachers' perceptions of the benefits and problems associated with part-time employment. It is essential that these opinions be validated with empirical research. The perceptions of teachers based on whether they are involved in part-time employment and the benefits and problems associated with these activities is an issue that needs to be addressed through research.

\section{Purpose of the Study}

The purpose of the research was to determine secondary agricultural educators' opinions on the benefits and problems associated with multiple occupational endeavors involving the teaching responsibilities of the agricultural education instructor and practical part-time farming, 
agribusiness, and/or other employment activities. Another aspect of the research was to identify the number of agricultural educators who were engaged in other part-time employment pursuits and to identify the nature of these endeavors.

\section{Objectives of the Study}

The primary objective of the research was to determine how West Virginia, Kentucky, and Ohio agricultural educators employed within a 150 mile radius of the Ripley, WV area perceive the benefits and problems of part-time farming, agribusiness, and/or other employment endeavors on professional job performance.

Secondary objectives include:

1. Identify the number of agricultural educators engaged in part-time farming, agribusiness, and/or other employment endeavors in West Virginia, Ohio, and Kentucky.

2. Determine the extent to which agricultural teachers supplement their income by means of part-time farming, agribusiness, and/or other employment enterprises.

3. Ascertain the degree to which part-time employment impacts an agriculture teacher's personal life.

4. Determine the influences on various components of the teacher's job as perceived by those same instructors when the teacher is employed in part-time farming, agribusiness, and/or other employment pursuits.

\section{Limitations of the Study}

The study was limited to West Virginia, Kentucky, and Ohio secondary agricultural educators who held positions teaching during the 2000-01 school year. The study was further limited to teachers employed in a 150-mile radius of the Ripley, West Virginia area. The data 
collection efforts were limited to self-reported perceptions of the effects of farming, agribusiness, and/or other employment involvement on job performance of the agricultural educator.

\section{$\underline{\text { Definitions }}$}

The following terms are important to the understanding of concepts discussed in this study:

Part-time employment: refers to employment endeavors that are in addition to a full-

time career, including year-round and seasonal activities. It was assumed that teaching secondary agricultural education was the full-time career.

Moonlighting: the holding of a second job in addition to a regular one (Merriam Webster Dictionary 1999).

Multiple job holding: These are employed persons who had either two or more jobs as a wage and salary worker, were self-employed and held a wage and salary job, or worked as an unpaid family worker and also held a wage and salary job (Bureau of Labor Statistics 1999). 


\section{CHAPTER II}

\section{REVIEW OF LITERATURE}

Moonlighting is commonly understood as holding a second job in addition to a regular one (Webster, 1999). The Bureau of Labor Statistics goes beyond the dictionary definition in describing moonlighting by calling the practice 'Multiple Jobholding' (1999). According to the Bureau of Labor Statistics, over seven million Americans work at more than one job. Most of the existing research makes one of two basic assumptions about why people moonlight. The reasons for moonlighting are because they need to (financial explanation) or because they want to (enjoy variety and challenges) (Betts, 2000).

Many teachers moonlight. In fact, approximately $15 \%$ of public school teachers in the US hold more than one job during the academic year (Bobbitt, 1988, 1990). There are countless journal articles on the subject from teachers who have had to supplement their income. For many teachers, moonlighting is an economic necessity. Dedication to their students and a love of teaching inspire them to remain in the field, but they have trouble making ends meet (Ladestro, 1990). In contrast to this article, another reported that farmers often need to moonlight in nonfarm jobs in order to remain in the business (Daly, 1981). In Moonlighting Professionals: A Study of Full-Time Teachers and Their Part-Time Work, Carroll (1994) found that moonlighters tend to be younger, better educated, and less satisfied with current employment than other teachers. In several studies, results suggest that moonlighting is an attempt to raise living standards (Pearson, 1994). Traditionally teachers' jobs have been conducive to the moonlighting lifestyle. They have many days off during the school year and in most cases, their summers are free. Their daytime hours are for the most part fairly regular, thus affording the would-be moonlighter the chance to take an evening job with another set of regular hours. 
Teachers have relatively low paying jobs, compared to other professionals, and this also sets the stage for a moonlighting scenario. Although salaries are part of moonlighting's attractiveness to teachers, the occasional and short-lived character of many moonlighting spells suggests that teachers often take second jobs in order to meet short-term cash flow problems (Ballou, 1995). For other teachers, financial need is not the only reason for holding a second job (Ballou, 1995). Moonlighting studies as they relate to classroom performance are also abundant. Two recent studies suggest there are very different views on the subject. A series of surveys of Texas teachers has consistently found that a majority of those who moonlighted regarded it as detrimental to their teaching (Henderson \& Schlesinger, 1988). However, in another study, only nine percent of respondents to Raftel and Groff (1990) said that moonlighting impaired their teaching performance. Estimates from another study found no support for the view that moonlighting teachers spend substantially less time preparing lessons and grading papers than their colleagues (Ballou, 1995).

A profession is defined as a calling requiring specialized knowledge and academic preparation (Webster, 1999). Further, it is a principal employment. As teachers desire to be called professionals, do their secondary employment endeavors take away from this image of a professional? Moonlighting is said to detract from professionalism, thereby making it more difficult to attract capable persons into teaching (Bell \& Roach, 1988). Outside employment reduces the time teachers have to read professional journals, attend conferences, and otherwise keep up with developments in their fields (Boyer, 1983).

When a teacher moonlights in their chosen area of study, such as an accounting teacher being a tax preparer or an auto-body instructor with a car repair business outside of the school system, where are the lines drawn? Do people view this as a natural extension of the teacher's 
work at the school, or is it viewed as an interference? Do they see it as a validation of their teaching or a conflict of interest?

According to 1997 Census of Agriculture data, there were 10,627 operators of farms in West Virginia whose principal occupation was employment of a non-agricultural nature (Glickman, 1997). There has been much written on the subject of part-time farming, but little has been reported on the job performance of teachers of agriculture who engage in farming and/or agribusiness endeavors in addition to their teaching responsibilities.

Part-time farming has come to be recognized as a permanent component of the agricultural structure of developed countries (Gasson, 1986). A special issue of Cooperative Farmer Magazine devoted to part-time farming reported that:

The part-time farmer probably lives within 50 miles of a small city where he [sic] works; needs off-farm income of about $\$ 40,000$ to play the game; and typically spends about $\$ 7,000$ annually on expenses except land which he may own or rent cheaply, probably from a family member. He hopes to make a profit, prays to break even, and usually gets out to cut his losses if neither happens. (Graham, 1988, p. 3)

Although this paints a rather negative picture of the part-time agriculturist, it is, however, correct to assert that many part-time farmers and/or agribusiness persons possess valuable skills and competencies that make running these operations profitable.

The job of the vocational agriculture teacher is to incorporate a combination of technical knowledge, marketable skills, and profit making practices into the total program of instruction, which will produce students who are proficient to a degree that will allow for their establishment in production or an off-farm agricultural operation. Smith (1950) reports his findings by stating: 
We insist in vocational education that 'learning to do' results from 'doing' or guided participation. Shall we assume that this principle is as directly applicable in the training of teachers as it is in the preparation of a student for farming? (p. 51)

Teachers of agricultural education, because of the program's vocational framework, must impart the ability to perform various skills to their students. These acquired skills assist students in becoming proficient in the operation of supervised occupational experience programs. Many teachers of agricultural education are both teaching farming and working at farming. Do these situations, however, provide for a satisfactory combination? Employers have concerns when it comes to job performance, conflicts of interest, employer resources, and dangerous and controversial activities. As far as job performance is concerned, in some situations concerning multiple job holders' attitudes were actually better in moonlighters than non-moonlighters (Betts, 2000). Though employers may be able to see the possible harmful effects of multiple job holding endeavors, do their employees take stock of their lifestyle? If they do conduct these selfevaluations, are their personal findings enough to cause them to reevaluate their primary job duties and, in this case, provide their school board and students with the level of performance they deserve to receive?

A study by Harper (1991) was conducted with head teacher educators and state supervisors of agricultural education in the 48 contiguous states. The participants in this study identified twenty-two benefits and forty-two problems associated with part-time farming on the job performance of agricultural education teachers who engage in these activities. The head teacher educators and state supervisors rated the problems associated with part-time employment in farming or agribusiness higher than they did the benefits. 


\section{$\underline{\text { Summary of Literature Review }}$}

Although about 5 percent of all U.S. workers hold second jobs, 300,000 teachers or seventeen percent of America's 2 million teachers, were employed outside the school system

during the school year. According to Alley and Ballenger (1990), moonlighting adversely affects teacher recruitment, job stress, and teacher efficacy. Within this chapter, the research related to teacher moonlighting activities and agricultural educators' job performances have been explored. There was no current information concerning the number of agricultural educators who moonlight, the type of employment endeavors in which they participate, and if their job performance was harmed or enhanced as a result of the multiple job holdings. Since it is unlikely that these teachers would assess these variables on their own, the only way to determine the answers to these questions is to conduct research in this area of study. 


\section{CHAPTER III \\ METHODOLOGY}

$\underline{\text { Population }}$

The target population of the study was high school agricultural educators in West Virginia, Ohio, and Kentucky who were teaching during the 2000-01 school year. The population was further limited to those teaching within a 150-mile radius of Ripley, West Virginia. Lists were secured from State Supervisors and all teachers within this area were identified. It was determined that Ohio had a much larger number of agriculture teachers per district than those in the same area of West Virginia and Kentucky. Since the study was selffunded, and cost restraints were a factor, the decision was made to take a random sample of teachers from Ohio. A random sample procedure was used which included every third person from the census of secondary agricultural education teachers in Ohio's Regions 8 and 10, to include an accessible population similar to the number of teachers used in Kentucky and West Virginia. The accessible population was 108 secondary agricultural education teachers; 35 from West Virginia, 34 from Kentucky, and 38 from Ohio.

\section{$\underline{\text { Instrumentation }}$}

The questionnaire items used in this study were based on a list of benefits and problems of part-time employment of secondary agricultural education teachers identified by teacher educators and state supervisors (Harper, 1991). Part one of the questionnaire inquired about perceptions of the benefits and problems associated with part-time employment by secondary agricultural educators. Part two of the questionnaire collected demographic information of each participant such as state, age, and gender. 
The questionnaire was examined for content validity by faculty members at West Virginia University. The instrument was pilot tested using the West Virginia Agricultural Education Association's (WVAEA) Program and Policy Committee. The committee is made up of teacher educators at West Virginia University, state supervisors, state officers of the WVAEA, and presidents and/or vice-presidents representing each WVAEA region in West Virginia. A Cronbach's alpha reliability coefficient was calculated using data from questionnaires completed by the Program and Policy Committee members. The reliability coefficient of this instrument was .97. A copy of the instrument used in this study can be found in Appendix B. Requirements of the Human Subjects Review Board of West Virginia University were met.

\section{$\underline{\text { Research Questions }}$}

The following research questions were developed to guide the research:

1. How many secondary agricultural education teachers were involved in part-time employment activities?

2. In what types of employment activities are secondary agricultural education teachers involved?

3. What are the demographic characteristics of secondary agricultural educators?

4. What are the perceptions of agricultural educators on problems and benefits of agricultural educators being involved in part-time employment?

5. How do these perceptions differ based upon the various demographic characteristics?

\section{$\underline{\text { Research Design }}$}

A descriptive research design was selected to collect the data necessary to answer the research questions. "Descriptive data is usually collected by using observation, interviews, and questionnaires. Descriptive studies range from simple surveys to studies that present explicit 
statements about the relationships between variables which approach the level of the explanatory hypothesis one finds in experimental research" (VanDalen, 1979, p. 285). "Descriptive research methodology provides for the generation of large amounts of data in a limited time frame" (Kaplin, 1991, p. 24).

\section{$\underline{\text { Data Collection Procedures }}$}

A cover letter (Appendix A) was developed that explained the purpose of the study and gave directions for completing and returning the questionnaire. The letter was signed by the researcher and her advisor with a stamped, self-addressed envelope to facilitate the prompt return of the questionnaire.

The cover letter explained the research study, why their participation was important, instructions for returning the completed survey, assurance of confidentiality, and a nonobligation statement. Surveys were coded for the purpose of sending reminder post cards. Procedures for administering mail questionnaires as recommended by Dillman (1978) were followed to increase the response rate. The final survey was color-coded by state. To thank respondents for completing the survey and to expedite the return, a sharpened pencil personalized to say "Thank you for your time" was included.

Two weeks after initial surveys were mailed, a reminder post card (Appendix C) was sent to each non-respondent. A follow-up letter (Appendix D) and a second questionnaire were mailed to all non-respondents two weeks after the reminder post card. Early and late respondents were tracked during the data collection process.

\section{Analysis of Data}

Returned questionnaires were visually verified and entered in an Excel spreadsheet. The data were transferred to the personal computer version of the Statistical Package for the Social 
Sciences (SPSS). Data analysis procedures included frequencies and means to describe the population. Analysis of variance statistical procedures were used to determine differences among the population on key demographic variables including age, involvement in part-time production agriculture, involvement in part-time agribusiness, involvement in other part-time employment, years teaching experience, and length of teaching contract.

\section{$\underline{\text { Use of Findings }}$}

Findings from this study will be provided to the West Virginia University Library and to teacher educators and State Supervisors in West Virginia, Ohio and Kentucky. Based upon the results of this study, interested persons will be able to ascertain the extent to which agricultural educators are involved in part-time employment activity and to their perceptions on the benefits and problems associated with part-time employment. 


\section{CHAPTER IV}

\section{FINDINGS}

The purpose of the study was to determine secondary agricultural education teachers' perceptions of the benefits and/or problems of part-time employment on the job performance of high school agricultural education teachers. The study was limited to secondary agricultural educators in West Virginia, Ohio, and Kentucky who were located within a 150-mile radius of Ripley, West Virginia. To accomplish this goal, 108 teachers were surveyed using the questionnaire in Appendix B.

The primary objective of the research was to determine how West Virginia, Kentucky, and Ohio agricultural educators employed within a 150 mile radius of the Ripley, WV area perceive the benefits and problems of part-time farming, agribusiness, and/or other employment endeavors have on professional job performances.

Secondary objectives include:

1. Identify the number of agricultural educators engaged in part-time farming, agribusiness, and/or other employment endeavors in West Virginia, Ohio, and Kentucky.

2. Determine the extent to which agricultural teachers supplement their income by means of part-time farming, agribusiness, and/or other employment enterprises.

3. Ascertain the degree to which part-time employment impacts an agriculture teacher's personal life.

4. Determine the influences on various components of the teacher's job as perceived by those same instructors when the teacher is employed in part-time farming, agribusiness, and/or other employment pursuits. 


\section{$\underline{\text { Survey Return Information }}$}

The accessible population consisted of 108 secondary agricultural educators in West Virginia, Ohio, and Kentucky. Seventy-three questionnaires (68\%) were returned. Of the 73 questionnaires returned, four were unusable. The final set of useable surveys numbered 69 $(63.9 \%)$.

The cover letter and questionnaire were initially mailed on January 18, 2001. Fifty-three secondary agricultural educators completed and returned the questionnaire. Reminder post cards were mailed two weeks later. The post cards yielded no returns. A follow-up letter and a second questionnaire were mailed on February 8, 2001. From this mailing, 20 additional questionnaires were returned. A summary of the response rate by state and phase of data collection is presented in Table 1.

The data obtained from the questionnaire were reviewed and entered into a Microsoft Excel spreadsheet. The data were analyzed using the Statistical Package for Social Sciences for Windows (SPSS). Data analysis procedures included frequencies and means to describe the population. Analysis of variance statistical procedures were used to determine differences among the population on key demographic variables. The level of significance was set a priori at $\mathrm{p}<0.05$.

Analyses of variance were used to compare early and late respondents' perceptions of each of the benefits and problems associated with part-time employment by secondary agricultural education teachers. No significant differences were found between the groups on any of the perceived benefits or problems; therefore, generalizations made included the entire population of the study. 
Table 1

Number of Surveys or Reminders and Associated Response Rate by State Following Each Phase of Data Collection.

\begin{tabular}{lcccc}
\hline \multicolumn{1}{c}{ State } & $\begin{array}{c}\text { Total Number } \\
\text { Mailed }\end{array}$ & Responses Early & Responses Late & Response Rate \\
\hline West Virginia & 35 & 32 & 0 & $91 \%$ \\
Kentucky & 34 & 8 & 11 & $56 \%$ \\
Ohio & 38 & 13 & 9 & $58 \%$ \\
TOTAL & 108 & 53 & 20 & $68 \%$ \\
\hline
\end{tabular}

The strategy of mailing a second questionnaire along with the follow-up letter increased the response rate. A reminder card was sent in between the two survey mailings, however no responses were returned from this effort. Since comparisons between teachers who were involved in part-time employment in addition to their regular agricultural teaching duties and those who were not involved in part-time employment were planned, an ample number of responses was needed from those engaged in these other pursuits. Of the 69 useable questionnaires, 41 of the respondents (59\%) were employed in part-time employment endeavors, which supplemented between 1-10\% of their total income. A breakdown of the supplemented income totals is found in Table 3.

The questionnaire was composed of a list of benefits and problems associated with parttime employment previously identified by teacher educators and state supervisors in a study conducted by Harper (1991). Participants were asked to rate each benefit and problem with the following scale: strongly disagree, disagree, no effect, agree, or strongly agree

Data analysis procedures included frequencies and means to describe the population. Analysis of variance statistical procedures were used to determine differences among the population on key demographic variables. The significance level was set a priori at .05 . 


\section{$\underline{\text { Demographic Data }}$}

Sixty-three of the respondents $(92 \%)$ were male, while five $(7.4 \%)$ were female. Thirtyseven respondents $(54.4 \%)$ were over the age of 40 with seven of the respondents $(7.4 \%)$ still teaching after the age of 65 . Fifty respondents $(74.0 \%)$ had over 10 years teaching experience while seventeen $(25 \%)$ had taught over 25 years.

Forty respondents $(59.7 \%)$ were engaged in part-time employment activities. Thirty-five respondents $(51.5 \%)$ were involved in production agriculture endeavors. Twelve respondents $(17.6 \%)$ were involved in agribusiness occupations. Seven respondents $(10.3 \%)$ were involved in other non-agriculture employment. It should be noted that some teachers were involved in more than one category of part-time employment, therefore the total number of teachers involved in part-time employment is less than the total of those involved in part-time production agriculture, agribusiness, and other employment activities.

Of those respondents who moonlighted, however, nineteen respondents $(46.3 \%)$ reported the part-time employment accounted for only $1-10 \%$ of their gross income. Respondents from Kentucky generated the highest percentage of their gross income from their part-time activity with five $(41.7 \%)$ respondents receiving $25-50 \%$ of their gross income from their part-time endeavors. Overall, there were seven respondents (17.1\%) involved in part-time employment earning $11-25 \%$ of gross, while nine respondents $(22.0 \%)$ earned at least $25-50 \%$ of their income from part-time employment endeavors.

Twenty respondents $(48.8 \%)$ reported working between 11 and 20 hours per week in their part-time employment. Twelve respondents (29.3\%) reported working between 21 and 30 hours per week in their part-time employment. Two respondents $(8.4 \%)$ reported working in excess of 30 hours per week in their part-time employment. 
Twenty-six respondents (38.2\%) had a teaching contract less than 12 months. There were three teachers $(4.4 \%)$ employed on a 9-month contract. Forty-two teachers $(61.8 \%)$ were on 12-month contracts. Kentucky had the largest percentage of 12-month contracts with 13 $(81.3 \%)$.

Thirty-two teachers $(47.8 \%)$ were employed in a one-teacher department. Six teachers (9.0\%) reported working in a six-teacher department. The data are reported in Tables 2 and 3. Table 2

Demographic Characteristics of Respondents Reported by State

\begin{tabular}{|c|c|c|c|c|c|c|c|c|}
\hline & \multicolumn{2}{|c|}{ Total } & \multicolumn{2}{|c|}{ Kentucky } & \multicolumn{2}{|c|}{ Ohio } & \multicolumn{2}{|c|}{$\begin{array}{c}\text { West } \\
\text { Virginia }\end{array}$} \\
\hline & $\underline{\mathrm{N}}$ & $\%$ & $\underline{\mathrm{N}}$ & $\%$ & $\underline{\mathrm{N}}$ & $\%$ & $\underline{\mathrm{N}}$ & $\%$ \\
\hline \multicolumn{9}{|l|}{ Gender } \\
\hline Male & 63 & 92.6 & 14 & 87.5 & 20 & 90.9 & 29 & 96.7 \\
\hline Female & 5 & 7.4 & 2 & 12.5 & 2 & 9.1 & 1 & 7.4 \\
\hline \multicolumn{9}{|l|}{ Age } \\
\hline 21-25 years & 6 & 8.8 & 0 & 0 & 2 & 9.1 & 4 & 13.3 \\
\hline 26-30 years & 6 & 8.8 & 0 & 0 & 1 & 4.5 & 5 & 16.7 \\
\hline $31-35$ years & 6 & 8.8 & 2 & 12.5 & 1 & 4.5 & 3 & 10.0 \\
\hline $36-40$ years & 10 & 14.7 & 4 & 25.0 & 3 & 13.6 & 3 & 10.0 \\
\hline $41-45$ years & 13 & 19.1 & 2 & 12.5 & 6 & 27.3 & 5 & 16.7 \\
\hline $46-50$ years & 10 & 14.7 & 4 & 25.0 & 1 & 4.5 & 5 & 16.7 \\
\hline $51-55$ years & 9 & 13.2 & 4 & 25.0 & 1 & 4.5 & 4 & 13.3 \\
\hline Over 65 years & 5 & 7.4 & 0 & 0 & 5 & 22.7 & 0 & 0 \\
\hline Missing & 3 & 4.4 & 0 & 0 & 2 & 9.1 & 1 & 3.3 \\
\hline \multicolumn{9}{|l|}{ Department } \\
\hline 1 teacher & 32 & 47.8 & 6 & 37.5 & 11 & 52.4 & 15 & 50.0 \\
\hline 2 teachers & 16 & 23.9 & 3 & 18.8 & 4 & 19.0 & 9 & 30.0 \\
\hline 3 teachers & 10 & 14.9 & 5 & 31.3 & 0 & 0 & 5 & 16.7 \\
\hline 4 teachers & 2 & 3.0 & 1 & 6.3 & 1 & 4.8 & 0 & 0 \\
\hline 5 teachers & 1 & 1.5 & 1 & 6.3 & 0 & 0 & 0 & 0 \\
\hline 6 or more teachers & 6 & 9.0 & 0 & 0 & 5 & 23.8 & 1 & 3.3 \\
\hline
\end{tabular}


Table 2 (Continued)

\begin{tabular}{|c|c|c|c|c|c|c|c|c|}
\hline & \multicolumn{2}{|c|}{ Total } & \multicolumn{2}{|c|}{ Kentucky } & \multicolumn{2}{|c|}{ Ohio } & \multicolumn{2}{|c|}{$\begin{array}{c}\text { West } \\
\text { Virginia }\end{array}$} \\
\hline & $\underline{\mathrm{N}}$ & $\%$ & $\underline{\mathrm{N}}$ & $\%$ & $\underline{\mathrm{N}}$ & $\%$ & $\underline{\mathrm{N}}$ & $\%$ \\
\hline \multicolumn{9}{|l|}{ Teaching Experience } \\
\hline Less than one year & 4 & 5.9 & 2 & 12.5 & 0 & 0 & 2 & 6.7 \\
\hline $1-5$ years & 9 & 13.2 & 0 & 0 & 4 & 18.2 & 5 & 16.7 \\
\hline $6-10$ years & 5 & 7.4 & 2 & 12.5 & 0 & 0 & 3 & 10.0 \\
\hline $11-15$ years & 10 & 14.7 & 3 & 18.8 & 4 & 18.2 & 3 & 10.0 \\
\hline $16-20$ years & 11 & 16.2 & 3 & 18.8 & 4 & 18.2 & 4 & 13.3 \\
\hline $21-25$ years & 12 & 17.6 & 3 & 18.8 & 3 & 13.6 & 6 & 20.0 \\
\hline More than 25 years & 17 & 25 & 3 & 18.8 & 7 & 31.8 & 7 & 23.3 \\
\hline \multicolumn{9}{|l|}{ Teaching Contract } \\
\hline 12 months & 42 & 61.8 & 13 & 81.3 & 9 & 40.9 & 20 & 66.7 \\
\hline 11 months & 11 & 16.2 & 0 & 0 & 6 & 27.3 & 5 & 16.2 \\
\hline 10 months & 9 & 13.2 & 1 & 6.3 & 4 & 18.2 & 4 & 13.3 \\
\hline 9 months & 3 & 4.4 & 0 & 0 & 3 & 13.6 & 0 & 0 \\
\hline Other & 3 & 4.4 & 2 & 12.5 & 0 & 0 & 1 & 3.3 \\
\hline \multicolumn{9}{|c|}{ Years Part-time Employment } \\
\hline Less than one year & 1 & 2.4 & 0 & 0 & 0 & 0 & 1 & 5.9 \\
\hline $1-5$ years & 5 & 12.2 & 2 & 16.7 & 2 & 16.7 & 1 & 5.9 \\
\hline $6-10$ years & 2 & 4.9 & 0 & 0 & 1 & 8.3 & 1 & 5.9 \\
\hline $11-15$ years & 6 & 14.6 & 2 & 16.7 & 3 & 25.0 & 1 & 5.9 \\
\hline $16-20$ years & 1 & 2.4 & 0 & 0 & 0 & 0 & 1 & 5.9 \\
\hline $21-25$ years & 6 & 14.6 & 2 & 16.7 & 1 & 8.3 & 3 & 17.6 \\
\hline More than 25 years & 20 & 48.8 & 6 & 50.0 & 5 & 41.7 & 9 & 52.9 \\
\hline
\end{tabular}


Table 3

Demographic Data as it Relates to Involvement in Part-Time Employment

\begin{tabular}{|c|c|c|c|c|c|c|c|c|}
\hline & \multicolumn{2}{|c|}{ Total } & \multicolumn{2}{|c|}{ Kentucky } & \multicolumn{2}{|c|}{ Ohio } & \multicolumn{2}{|c|}{$\begin{array}{c}\text { West } \\
\text { Virginia }\end{array}$} \\
\hline & $\underline{\mathrm{N}}$ & $\%$ & $\underline{\mathrm{N}}$ & $\%$ & $\underline{\mathrm{N}}$ & $\%$ & $\underline{\mathrm{N}}$ & $\%$ \\
\hline \multicolumn{9}{|c|}{ Part-time Employment - All Types } \\
\hline No & 27 & 39.7 & 4 & 25.0 & 10 & 45.5 & 13 & 43.3 \\
\hline Yes & 41 & 60.3 & 12 & 75.0 & 12 & 54.5 & 17 & 56.7 \\
\hline
\end{tabular}

Part-time Agriculture Employment

$\begin{array}{lrrrrrrrr}\text { No } & 33 & 48.5 & 5 & 31.3 & 12 & 54.5 & 16 & 53.3 \\ \text { Yes } & 35 & 51.5 & 11 & 68.8 & 10 & 45.5 & 14 & 46.7\end{array}$

Part-time Agribusiness Employment

$\begin{array}{lrrrrrrrr}\text { No } & 56 & 82.4 & 14 & 87.5 & 19 & 86.4 & 23 & 76.7 \\ \text { Yes } & 12 & 17.6 & 2 & 12.5 & 3 & 13.6 & 7 & 23.3\end{array}$

Part-time Other Employment

$\begin{array}{lrrrrrrrr}\text { No } & 61 & 89.7 & 15 & 93.8 & 20 & 90.9 & 26 & 86.7 \\ \text { Yes } & 7 & 10.3 & 1 & 6.3 & 2 & 9.1 & 4 & 13.3\end{array}$

Percentage of Gross Income

$\begin{array}{lrrrrrrrr}1-10 \% & 19 & 46.3 & 3 & 25.0 & 6 & 50.0 & 10 & 58.8 \\ 11-25 \% & 7 & 17.1 & 2 & 16.7 & 4 & 33.3 & 1 & 5.9 \\ 25-50 \% & 9 & 22.0 & 5 & 41.7 & 1 & 8.3 & 3 & 17.6 \\ 51-75 \% & 5 & 12.2 & 2 & 16.7 & 0 & 0 & 3 & 17.6 \\ 76 \% \text { or more } & 1 & 2.4 & 0 & 0 & 1 & 8.3 & 0 & 0\end{array}$

Hours Part-Time Employment per Week

\begin{tabular}{lrrrrrrrr}
$1-10$ hours & 7 & 17.1 & 1 & 8.3 & 2 & 16.7 & 4 & 23.5 \\
$11-20$ hours & 20 & 48.8 & 7 & 58.3 & 4 & 33.3 & 9 & 52.9 \\
$21-30$ hours & 12 & 29.3 & 4 & 33.3 & 5 & 41.7 & 3 & 17.6 \\
$31-40$ hours & 1 & 2.4 & 0 & 0 & 0 & 0 & 1 & 5.9 \\
40 hours or more & 1 & 2.4 & 0 & 0 & 1 & 8.3 & 0 & 0 \\
\hline
\end{tabular}


Perceived Benefits and Problems of the Agricultural Education Program which Result from the Teacher's Part-time Employment

The benefits to the agricultural education program which result from the teacher's parttime employment as perceived by secondary school agricultural educators were analyzed and ranked (Table 4). Respondents agreed that all 12 items were beneficial to the program as represented by a mean of 3.54 or greater. The highest ranking benefits were "teachers develop new knowledge and skill" (4.37), "teachers gain experience" (4.27), "provides work experience" (4.22), "overcome financial needs - low salaries" (4.16), "source of instructional examples" (4.08), and "teachers stay up-to-date" (4.01)."

The teacher's perceptions of problems associated with part-time employment were also analyzed and ranked (Table 5). The items considered to be the greatest problems were: "forces teachers to make judgments about time usage" (4.02), "conflict of interest - using agricultural education facilities" (3.87), "can become a second full-time job” (3.79), " lack of time to spend with family" (3.76), and " time not available when greatest need arises" (3.74). Twenty-four of the problems had a mean score greater than 3.00. Fifteen of the problems had a mean score less than 3.00. The five items ranked the lowest by respondents (disagreement on the fact that the item was a problem) were "teachers teach content of part-time employment" (2.20), "results in a poor instructional program" (2.52), "tarnishes the professional image of agricultural education teachers" (2.53), teacher loses broader perspective of agriculture" (2.61), and "decreased importance of agricultural education" (2.67). 
Comparison of Perceived Benefits to the Agricultural Education Program Which Result from the Teacher's Part-time Employment by Involvement in Part-time Production Agriculture

Analyses of variance were used to determine if differences existed between the perceptions of the benefits to the agricultural program when compared by those individuals involved in part-time production agriculture and those who were not involved in part-time agriculture occupations (Table 4). Significant differences existed between the groups on each of the following twelve items: "teachers develop new knowledge and skill," "teachers gain experience," "provides work experience," “overcome financial needs-low salaries," "source of instructional examples," "teachers stay up-to-date," "broadens outlook about agriculture," "keeps teacher aware of industry problems," "means to validate course content," "cultivates student employment opportunities," "enhances teacher confidence," and "helps attitude-prevents burnout." In each of the twelve items agricultural educators involved in part-time production agriculture rated the benefit higher than did their non part-time agricultural educator counterparts.

Comparison of Perceived Problems of the Agricultural Education Program which Result from the Teacher's Part-time Employment, According to Involvement in Production Agriculture

Analyses of variance were used to determine if differences existed between the perceptions of the benefits to the agricultural program when compared by those individuals involved in part-time production agriculture and those who were not involved in part-time agriculture occupations (Table 5). Significant differences existed in the perceptions of agricultural education involved in part-time production agriculture and those who were not involved in part-time agriculture occupations on the following items: "a cause of relationship problems with school officials," "lack of time to devote to FFA activities," "time not available 
Table 4

Perceived Benefits to the Agricultural Education Program which Result from the Teacher's Part$\underline{\text { time Employment, According to Involvement in Part-time Production Agriculture }}$

\begin{tabular}{|c|c|c|c|c|}
\hline \multirow[t]{2}{*}{ Benefits } & \multirow{2}{*}{$\begin{array}{c}\text { Overall } \\
\text { Mean } \\
\underline{N}=68\end{array}$} & \multicolumn{2}{|c|}{ Involvement } & \multirow[t]{2}{*}{ F-Value } \\
\hline & & $\begin{array}{c}\mathrm{No} \\
\underline{N}=33\end{array}$ & $\begin{array}{c}\text { Yes } \\
\underline{N}=35\end{array}$ & \\
\hline $\begin{array}{l}\text { Teachers develop new knowledge and } \\
\text { skill. }\end{array}$ & 4.37 & 4.18 & 4.55 & $4.15^{*}$ \\
\hline Teachers gain experience & 4.27 & 4.05 & 4.50 & $4.71 *$ \\
\hline Provides work experience. & 4.22 & 3.91 & 4.52 & $14.66^{* *}$ \\
\hline Overcome financial needs-low salaries. & 4.16 & 3.94 & 4.38 & $4.05^{*}$ \\
\hline Source of instructional examples. & 4.08 & 3.70 & 4.47 & $14.11 * *$ \\
\hline Teachers stay up-to-date. & 4.01 & 3.70 & 4.33 & $5.92 *$ \\
\hline Broadens outlook about agriculture. & 3.97 & 3.57 & 4.35 & $13.75^{* *}$ \\
\hline Keeps teacher aware of industry problems. & 3.94 & 3.57 & 4.29 & $7.90 * *$ \\
\hline Means to validate course content & 3.91 & 3.57 & 4.23 & $10.25^{* *}$ \\
\hline $\begin{array}{l}\text { Cultivates student employment } \\
\text { opportunities. }\end{array}$ & 3.77 & 3.48 & 4.05 & $5.98^{*}$ \\
\hline Enhances teacher confidence. & 3.56 & 3.12 & 4.00 & $9.83 * *$ \\
\hline Helps attitude-prevents burnout. & 3.54 & 2.90 & 4.14 & $16.75^{* *}$ \\
\hline
\end{tabular}

*F-value significant at .05

$* *$ F-value significant at .01

Rating scale: 1-Strongly disagree, 2-Disagree, 3-No effect, 4-Agree, 5-Strongly agree

when greatest need arises," "causes teaching to become part-time employment," "emergencies

must be handled regardless of school commitments," "decline in dedication to teaching,"

"demonstrates that teaching is not a full time commitment," "encourages part-time agriculture

programs," "alienation if teacher operates a competing agribusiness," "conflict of interest - using agricultural education facilities," "public image problem - double dipping," " problem - working for the school or themselves," "image of agricultural teaching less important than other teaching areas," "teacher loses broader perspective of agriculture," " teachers teach content of part-time 
employment," " difficult to serve two masters," " reduces teaching contracts for all agriculture teachers," "school administrators recognize programs as part-time," and "administrators question if SAE visits are real." Agricultural educators involved in part-time employment rated each of the twenty-one problems lower than their non part-time agricultural education counterparts. The agricultural educators involved in part-time production agriculture perceived the items less of a problem than teachers not involved in part-time production agriculture. The reader should note that the "not involved in production agriculture" included teachers who were not involved in part-time employment as well as those who were involved in part-time agribusiness and other part-time occupations.

Table 5

Perceived Problems of the Agricultural Education Program which Result from the Teacher's $\underline{\text { Part-time employment, According to Involvement in Production Agriculture }}$

\begin{tabular}{|c|c|c|c|c|}
\hline \multirow[t]{2}{*}{ Problems } & \multirow{2}{*}{$\begin{array}{c}\text { Overall } \\
\text { Mean } \\
\underline{N}=68\end{array}$} & \multicolumn{2}{|c|}{ Involvement } & \multirow[t]{2}{*}{ F-Value } \\
\hline & & $\begin{array}{c}\mathrm{No} \\
\underline{N}=33\end{array}$ & $\begin{array}{c}\text { Yes } \\
\underline{N}=35\end{array}$ & \\
\hline $\begin{array}{l}\text { Forces teachers to make judgments about } \\
\text { time usage. }\end{array}$ & 4.02 & 4.15 & 3.88 & 1.88 \\
\hline $\begin{array}{l}\text { Conflict of interest - using agricultural } \\
\text { education facilities. }\end{array}$ & 3.87 & 4.21 & 3.53 & $6.26 *$ \\
\hline Can become a second full-time job. & 3.79 & 3.79 & 3.79 & 0.00 \\
\hline Lack of time to spend with family & 3.76 & 3.94 & 3.58 & 1.70 \\
\hline Time not available when greatest need arises. & 3.74 & 4.06 & 3.41 & $6.48 *$ \\
\hline $\begin{array}{l}\text { Relationships with students that could } \\
\text { become public relations problems. }\end{array}$ & 3.45 & 3.62 & 3.27 & 1.78 \\
\hline Lack of time to devote to FFA Activities. & 3.42 & 3.88 & 2.94 & $9.25 * *$ \\
\hline Lack of time to supervise students. & 3.41 & 3.69 & 3.15 & 3.63 \\
\hline Lack of time to teach Young/Adult Farmers. & 3.38 & 3.63 & 3.13 & 3.06 \\
\hline Abuse of summer (extended) employment. & 3.37 & 3.70 & 3.06 & $4.74 *$ \\
\hline
\end{tabular}


Table 5 (Continued)

\begin{tabular}{|c|c|c|c|c|}
\hline \multirow[t]{2}{*}{ Problems } & \multirow{2}{*}{$\begin{array}{c}\begin{array}{c}\text { Overall } \\
\text { Mean }\end{array} \\
\underline{\mathrm{N}}=68\end{array}$} & \multicolumn{2}{|c|}{ Involvement } & \multirow[t]{2}{*}{ F-Value } \\
\hline & & $\begin{array}{c}\text { No } \\
\underline{N}=33\end{array}$ & $\begin{array}{c}\text { Yes } \\
\underline{\mathrm{N}}=35\end{array}$ & \\
\hline $\begin{array}{l}\text { Emergencies must be handled regardless of } \\
\text { school commitments. }\end{array}$ & 3.36 & 3.56 & 2.97 & $6.62 *$ \\
\hline Hinders lesson planning & 3.34 & 3.58 & 3.12 & 2.68 \\
\hline $\begin{array}{l}\text { Lack of time to attend in service/professional } \\
\text { activities }\end{array}$ & 3.29 & 3.59 & 3.00 & 3.93 \\
\hline $\begin{array}{l}\text { Alienation if teachers operate competing } \\
\text { agribusiness. }\end{array}$ & 3.25 & 3.65 & 2.85 & $7.69 * *$ \\
\hline Difficult to serve two masters. & 3.25 & 3.55 & 2.97 & $4.34^{*}$ \\
\hline $\begin{array}{l}\text { Concern about time spent away from official } \\
\text { duties. }\end{array}$ & 3.25 & 3.42 & 3.09 & 1.25 \\
\hline $\begin{array}{l}\text { Less contact with other staff and students in } \\
\text { the school system. }\end{array}$ & 3.21 & 3.66 & 2.80 & $8.58 * *$ \\
\hline $\begin{array}{l}\text { Teacher not willing to provide community } \\
\text { and industry services. }\end{array}$ & 3.13 & 3.33 & 2.94 & 1.69 \\
\hline Prevents doing both jobs well. & 3.11 & 3.39 & 2.82 & 3.05 \\
\hline $\begin{array}{l}\text { Lack of time for advisory committee } \\
\text { meetings. }\end{array}$ & 3.11 & 3.41 & 2.82 & 3.66 \\
\hline $\begin{array}{l}\text { Causes teaching to become part-time } \\
\text { employment. }\end{array}$ & 3.09 & 3.55 & 2.64 & $8.92 * *$ \\
\hline Encourages part-time agriculture programs. & 3.06 & 3.27 & 2.85 & $5.95^{*}$ \\
\hline $\begin{array}{l}\text { Problem-working for the school or } \\
\text { themselves. }\end{array}$ & 3.06 & 3.56 & 2.56 & $11.36^{* *}$ \\
\hline $\begin{array}{l}\text { Reduced teaching contracts for all } \\
\text { agricultural education teachers. }\end{array}$ & 3.06 & 3.47 & 2.69 & $6.44^{*}$ \\
\hline $\begin{array}{l}\text { Competition with others seeking } \\
\text { employment. }\end{array}$ & 3.00 & 3.21 & 2.79 & 2.53 \\
\hline Public image problem—double dipping. & 2.97 & 3.32 & 2.61 & $5.30^{*}$ \\
\hline Conflict of interest-hiring students. & 2.96 & 3.41 & 2.50 & $8.42 * *$ \\
\hline $\begin{array}{l}\text { Cause relationship problems with school } \\
\text { officials. }\end{array}$ & 2.93 & 3.41 & 2.44 & $12.49 * *$ \\
\hline $\begin{array}{l}\text { School administrators recognize programs as } \\
\text { part-time. }\end{array}$ & 2.92 & 3.29 & 2.59 & 5.68 \\
\hline
\end{tabular}


Table 5 (Continued)

\begin{tabular}{|c|c|c|c|c|}
\hline \multirow{2}{*}{ Problems } & \multirow{2}{*}{$\begin{array}{c}\begin{array}{c}\text { Overall } \\
\text { Mean }\end{array} \\
\underline{\mathrm{N}}=68\end{array}$} & \multicolumn{2}{|c|}{ Involvement } & \multirow{2}{*}{ F-Value } \\
\hline & & $\begin{array}{c}\text { No } \\
\mathrm{N}=33\end{array}$ & $\begin{array}{c}\text { Yes } \\
\underline{N}=35\end{array}$ & \\
\hline $\begin{array}{l}\text { Image of agricultural education teaching less } \\
\text { important than other teaching areas. }\end{array}$ & 2.91 & 3.23 & 2.50 & $6.45^{*}$ \\
\hline $\begin{array}{l}\text { Administrators question if SAE visits are } \\
\text { real. }\end{array}$ & 2.91 & 3.24 & 2.59 & $4.94 *$ \\
\hline $\begin{array}{l}\text { Causes a halt in FFA activities during the } \\
\text { summer. }\end{array}$ & 2.90 & 3.21 & 2.60 & 3.89 \\
\hline Decline in the dedication to teaching. & 2.85 & 3.24 & 2.45 & $5.95^{*}$ \\
\hline $\begin{array}{l}\text { Demonstrates that teaching is not a full time } \\
\text { commitment. }\end{array}$ & 2.82 & 3.33 & 2.30 & $8.88 * *$ \\
\hline Poor community involvement by teacher. & 2.73 & 3.00 & 2.47 & 3.16 \\
\hline $\begin{array}{l}\text { Decreased importance of agriculture } \\
\text { education. }\end{array}$ & 2.67 & 3.00 & 2.53 & 2.40 \\
\hline $\begin{array}{l}\text { Teacher loses broader perspective of } \\
\text { agriculture. }\end{array}$ & 2.61 & 3.00 & 2.26 & $7.43^{* *}$ \\
\hline $\begin{array}{l}\text { Tarnishes the professional image of } \\
\text { agriculture teachers. }\end{array}$ & 2.53 & 2.73 & 2.34 & 1.68 \\
\hline Results in a poor instructional program. & 2.52 & 2.81 & 2.24 & 3.66 \\
\hline $\begin{array}{l}\text { Teachers teach content of part-time } \\
\text { employment. }\end{array}$ & 2.20 & 2.48 & 1.94 & $5.67 *$ \\
\hline
\end{tabular}

*F-value significant at .05

**F-value significant at .01

Rating scale: 1-Strongly disagree, 2-Disagree, 3-No effect, 4-Agree, 5-Strongly agree

Comparison of Perceived Benefits of the Agricultural Education Program which Result from the

Teacher's Part-time Employment, According to Involvement in Part-time Agribusiness

Analyses of variance were used to determine if differences existed between the perceptions of the benefits to the agricultural education program by those involved in part-time agribusiness endeavors and those who were not involved in part-time agribusiness occupations. Significant differences existed on the mean score of two benefits "teachers stay up-to-date" and "enhances teacher confidence." In both situations, those teachers involved in agribusiness 
endeavors had a lower mean score than the teachers not involved in part-time agribusiness employment. The teachers involved in part-time agribusiness occupations did not view the items as much of a benefit as those not involved in agribusiness occupations (Table 6). The reader should note that the "not involved in agribusiness" included teachers who were not involved in part-time employment as well as those who were involved in part-time production agriculture and other part-time occupations.

Table 6

Perceived Benefits to the Agricultural Education Program which result from the Teacher's Part$\underline{\text { time Employment, According to Involvement in Agribusiness }}$

\begin{tabular}{|c|c|c|c|c|}
\hline \multirow[t]{2}{*}{ Benefits } & \multirow{2}{*}{$\begin{array}{c}\text { Overall } \\
\text { Mean } \\
\underline{N}=68\end{array}$} & \multicolumn{2}{|c|}{ Involvement } & \multirow[t]{2}{*}{ F-Value } \\
\hline & & $\begin{array}{l}\text { No } \\
\underline{N}=56\end{array}$ & $\begin{array}{c}\text { No } \\
\underline{N}=12\end{array}$ & \\
\hline Teachers develop new knowledge and skill & 4.37 & 4.45 & 4.00 & 3.15 \\
\hline Teachers gain experience & 4.28 & 4.33 & 4.00 & 1.39 \\
\hline Provides work experience & 4.22 & 4.26 & 4.00 & 1.20 \\
\hline Overcome financial needs - low salaries & 4.16 & 4.19 & 4.00 & 0.39 \\
\hline Source of instructional examples & 4.09 & 4.18 & 3.64 & 3.35 \\
\hline Teachers stay up-to-date & 4.01 & 4.18 & 3.18 & $8.50 *$ \\
\hline Broadens outlook about agriculture & 3.97 & 4.00 & 3.82 & 0.34 \\
\hline Keeps teacher aware of industry problems & 3.94 & 4.02 & 3.55 & 1.72 \\
\hline Means to validate course content & 3.91 & 3.96 & 3.63 & 1.23 \\
\hline Cultivates student employment opportunities & 3.78 & 3.84 & 3.45 & 1.38 \\
\hline Enhances teacher confidence & 3.57 & 3.70 & 2.91 & $3.99 *$ \\
\hline Helps attitude - prevents burn-out & 3.55 & 3.65 & 3.00 & 2.12 \\
\hline
\end{tabular}

*F-value significant at .05

**F-value significant at .01

Rating scale: 1-Strongly disagree, 2-Disagree, 3-No effect, 4-Agree, 5-Strongly agree 
Comparison of Perceived Problems of the Agricultural Education Program which Result from the Teacher's Part-time Employment, According to Involvement in Part-Time Agribusiness

Analyses of variance were used to determine if differences existed between the perceptions of problems to the agricultural education program by those involved in part-time agribusiness endeavors and those who were not involved in part-time agribusiness occupations. The only item which was significantly different was "results in a poor instructional program". Teachers who were involved in agribusiness endeavors rated the problem higher with a mean score of 3.25 while those not involved employment rated the same problem lower at 2.36. Teachers involved in part-time agribusiness viewed the item as a problem while those not involved in part-time agribusiness did not view it as a problem (Table 7). The reader should note that the "not involved in agribusiness" included teachers who were not involved in part-time employment as well as those who were involved in part-time production agriculture and parttime other occupations.

Table 7

Perceived Problems of the Agricultural Education Program which Result from the Teacher's Part-time Employment, According to Involvement in Agribusiness

\begin{tabular}{|c|c|c|c|c|}
\hline \multirow[t]{2}{*}{ Problems } & \multirow{2}{*}{$\begin{array}{c}\begin{array}{c}\text { Overall } \\
\text { Mean }\end{array} \\
\underline{N}=68\end{array}$} & \multicolumn{2}{|c|}{ Involvement } & \multirow[t]{2}{*}{ F-Value } \\
\hline & & $\begin{array}{c}\text { No } \\
\underline{N}=56 \\
\end{array}$ & $\begin{array}{c}\text { Yes } \\
\underline{N}=12 \\
\end{array}$ & \\
\hline $\begin{array}{l}\text { Forces teachers to make judgments about time } \\
\text { usage }\end{array}$ & 4.02 & 4.00 & 4.08 & 0.10 \\
\hline $\begin{array}{l}\text { Conflict of interest - using agricultural education } \\
\text { facilities }\end{array}$ & 3.87 & 3.84 & 4.00 & 0.19 \\
\hline Can become a second full-time job & 3.79 & 3.72 & 4.08 & 1.14 \\
\hline Lack of time to spend with family & 3.76 & 3.69 & 4.08 & 1.21 \\
\hline Time not available when greatest need arises & 3.74 & 3.69 & 4.00 & 0.78 \\
\hline
\end{tabular}


Table 7 (Continued)

\begin{tabular}{|c|c|c|c|c|}
\hline \multirow[t]{2}{*}{ Problems } & \multirow{2}{*}{$\begin{array}{l}\text { Overall } \\
\text { Mean } \\
\underline{\mathrm{N}}=68\end{array}$} & \multicolumn{2}{|c|}{ Involvement } & \multirow[t]{2}{*}{ F-Value } \\
\hline & & $\begin{array}{c}\mathrm{No} \\
\underline{\mathrm{N}}=56\end{array}$ & $\begin{array}{c}\text { Yes } \\
\mathrm{N}=12\end{array}$ & \\
\hline $\begin{array}{l}\text { Relationships with students that could become } \\
\text { public relations problems }\end{array}$ & 3.45 & 3.45 & 3.45 & 0.00 \\
\hline Lack of time to supervise students & 3.42 & 3.34 & 3.75 & 1.23 \\
\hline Lack of time to devote to FFA Activities & 3.42 & 3.44 & 3.33 & 0.07 \\
\hline Lack of time to teach Young/Adult Farmers & 3.38 & 3.34 & 3.55 & 0.28 \\
\hline Abuse of summer (extended) employment. & 3.37 & 3.32 & 3.58 & 0.43 \\
\hline $\begin{array}{l}\text { Emergencies must be handled regardless of } \\
\text { school commitments. }\end{array}$ & 3.36 & 3.35 & 3.41 & 0.02 \\
\hline Hinders lesson planning & 3.35 & 3.28 & 3.67 & 1.14 \\
\hline $\begin{array}{l}\text { Lack of time to attend in service/professional } \\
\text { activities }\end{array}$ & 3.29 & 3.28 & 3.33 & 0.02 \\
\hline $\begin{array}{l}\text { Alienation if teachers operate competing } \\
\text { agribusiness }\end{array}$ & 3.25 & 3.18 & 3.58 & 1.06 \\
\hline Difficult to serve two masters. & 3.25 & 3.20 & 3.50 & 0.67 \\
\hline $\begin{array}{l}\text { Concern about time spent away from official } \\
\text { duties. }\end{array}$ & 3.25 & 3.21 & 3.42 & 0.26 \\
\hline $\begin{array}{l}\text { Less contact with other staff and students in the } \\
\text { school system. }\end{array}$ & 3.21 & 3.15 & 3.50 & 0.78 \\
\hline $\begin{array}{l}\text { Teacher not willing to provide community and } \\
\text { industry services. }\end{array}$ & 3.13 & 3.07 & 3.42 & 0.75 \\
\hline Prevents doing both jobs well & 3.11 & 3.06 & 3.33 & 0.41 \\
\hline Lack of time for advisory committee meetings & 3.11 & 3.02 & 3.50 & 1.43 \\
\hline Causes teaching to become part-time employment & 3.09 & 3.00 & 3.50 & 1.44 \\
\hline Encourages part-time agriculture programs & 3.06 & 3.11 & 2.83 & 0.40 \\
\hline Working for the school or themselves questions. & 3.06 & 3.13 & 2.75 & 0.80 \\
\hline $\begin{array}{l}\text { Reduced teaching contracts for all agricultural } \\
\text { education teachers. }\end{array}$ & 3.06 & 3.02 & 3.25 & 0.30 \\
\hline Competition with others seeking employment. & 3.00 & 3.05 & 2.75 & 0.78 \\
\hline Public image problem—double dipping & 2.97 & 3.00 & 2.83 & 0.16 \\
\hline Conflict of interest-hiring students, & 2.96 & 3.02 & 2.67 & 0.65 \\
\hline Cause relationship problems with school officials & 2.93 & 2.95 & 2.83 & 0.08 \\
\hline
\end{tabular}


Table 7 (Continued)

\begin{tabular}{|c|c|c|c|c|}
\hline \multirow[t]{2}{*}{ Problems } & \multirow{2}{*}{$\begin{array}{c}\text { Overall } \\
\text { Mean } \\
\underline{N}=68\end{array}$} & \multicolumn{2}{|c|}{ Involvement } & \multirow[t]{2}{*}{ F-Value } \\
\hline & & $\begin{array}{l}\text { No } \\
\underline{N}=56\end{array}$ & $\begin{array}{c}\text { Yes } \\
\mathrm{N}=12\end{array}$ & \\
\hline $\begin{array}{l}\text { School administrators recognize programs as part- } \\
\text { time. }\end{array}$ & 2.92 & 2.87 & 3.17 & 0.58 \\
\hline $\begin{array}{l}\text { Image of agricultural education teaching less } \\
\text { important than other teaching areas. }\end{array}$ & 2.91 & 2.89 & 3.08 & 0.22 \\
\hline Administrators question if SAE visits are real. & 2.91 & 2.89 & 3.00 & 0.07 \\
\hline $\begin{array}{l}\text { Causes a halt in FFA activities during the } \\
\text { summer. }\end{array}$ & 2.90 & 2.86 & 3.08 & 0.29 \\
\hline Decline in the dedication to teaching & 2.85 & 2.80 & 3.08 & 0.43 \\
\hline $\begin{array}{l}\text { Demonstrates that teaching is not a full time } \\
\text { commitment. }\end{array}$ & 2.82 & 2.74 & 3.17 & 0.80 \\
\hline Decreased importance of agriculture education & 2.76 & 2.75 & 2.83 & 0.05 \\
\hline Poor community involvement by teacher. & 2.73 & 2.80 & 2.42 & 0.94 \\
\hline Teacher loses broader perspective of agriculture. & 2.61 & 2.49 & 3.17 & 3.42 \\
\hline $\begin{array}{l}\text { Tarnishes the professional image of agriculture } \\
\text { teachers. }\end{array}$ & 2.53 & 2.52 & 2.58 & 0.03 \\
\hline Results in a poor instructional program & 2.52 & 2.36 & 3.25 & $5.54 *$ \\
\hline Teachers teach content of part-time employment & 2.21 & 2.14 & 2.50 & 1.35 \\
\hline
\end{tabular}

*F-value significant at .05

**F-value significant at .01

Rating scale: 1-Strongly disagree, 2-Disagree, 3-No effect, 4-Agree, 5-Strongly agree

Comparisons of Perceived Benefits to the Agricultural Education Program which Result from the

Teacher's Part-time Employment, According to Involvement in Other Employment

Analyses of variance were used to determine if differences existed between the perceptions of benefits to the agricultural education program by those involved in other employment endeavors and those who were not involved in other part-time occupations. The two groups were significantly different on two benefits. The teachers who were involved in other (non-farm) employment rated "source of instructional examples" and "teachers stay up-to- 
date" lower than teachers not involved in part-time employment activities. Teachers who were involved in other (non-farm) employment saw the items as less of benefit than teachers not involved in other part-time occupations (Table 8). The reader should note that the "not involved in other occupations" included teachers who were not involved in part-time employment as well as those who were involved in part-time production agriculture and part-time agribusiness occupations.

Table 8

Perceived Benefits to the Agricultural Education Program which Result from the Teacher's Part$\underline{\text { time Employment, According to Involvement in Other Employment Endeavors }}$

\begin{tabular}{|c|c|c|c|c|}
\hline \multirow{2}{*}{ Benefits } & \multirow{2}{*}{$\begin{array}{c}\begin{array}{c}\text { Overall } \\
\text { Mean }\end{array} \\
\underline{N}=68\end{array}$} & \multicolumn{2}{|c|}{ Involvement } & \multirow{2}{*}{ F-Value } \\
\hline & & $\begin{array}{c}\mathrm{No} \\
\mathrm{N}=61\end{array}$ & $\begin{array}{l}\text { Yes } \\
\underline{N}=7\end{array}$ & \\
\hline Teachers develop new knowledge and skill & 4.37 & 4.43 & 3.86 & 3.60 \\
\hline Teachers gain experience & 4.28 & 4.34 & 3.71 & 3.49 \\
\hline Provides work experience & 4.22 & 4.26 & 3.86 & 1.96 \\
\hline Overcome financial needs - low salaries & 4.16 & 4.21 & 3.71 & 1.85 \\
\hline Source of instructional examples & 4.09 & 4.16 & 3.43 & $4.30 *$ \\
\hline Teachers stay up-to-date & 4.01 & 4.12 & 3.14 & $5.29 *$ \\
\hline Broadens outlook about agriculture & 3.97 & 4.00 & 3.71 & 0.58 \\
\hline Keeps teacher aware of industry problems & 3.94 & 4.02 & 3.29 & 2.85 \\
\hline Means to validate course content & 3.91 & 3.97 & 3.43 & 2.28 \\
\hline Cultivates student employment opportunities & 3.78 & 3.83 & 3.29 & 1.92 \\
\hline Enhances teacher confidence & 3.57 & 3.65 & 2.86 & 2.71 \\
\hline Helps attitude - prevents burn-out & 3.55 & 3.58 & 3.29 & 0.28 \\
\hline
\end{tabular}

*F-value significant at .05

$* *$ F-value significant at .01

Rating scale: 1-Strongly disagree, 2-Disagree, 3-No effect, 4-Agree, 5-Strongly agree 
Comparisons of Perceived Problems to the Agricultural Education Program which Result from the Teacher's Part-time Employment, According to Involvement in Other Employment

Analyses of variance were used to determine if differences existed between the perceptions of problems to the agricultural education program by those involved in other employment endeavors and those who were not involved in other part-time occupations. No significant differences were found between teachers involved in other employment and those who were not engaged in other part-time employment (Table 9).

Table 9

Perceived Problems of the Agricultural Education Program which Result from the Teacher's $\underline{\text { Part-time Employment, According to Involvement in Other Employment Endeavors }}$

\begin{tabular}{|c|c|c|c|c|}
\hline \multirow[t]{2}{*}{ Problems } & \multirow{2}{*}{$\begin{array}{c}\text { Overall } \\
\text { Mean } \\
\underline{N}=68\end{array}$} & \multicolumn{2}{|c|}{ Involvement } & \multirow[t]{2}{*}{ F-Value } \\
\hline & & $\begin{array}{l}\text { No } \\
\underline{N}=61\end{array}$ & $\begin{array}{l}\text { Yes } \\
\underline{N}=7\end{array}$ & \\
\hline $\begin{array}{l}\text { Forces teachers to make judgments about time } \\
\text { usage }\end{array}$ & 4.02 & 4.00 & 4.14 & 0.19 \\
\hline $\begin{array}{l}\text { Conflict of interest - using agricultural education } \\
\text { facilities }\end{array}$ & 3.87 & 3.85 & 4.00 & 0.10 \\
\hline Can become a second full-time job & 3.79 & 3.78 & 3.86 & 0.03 \\
\hline Lack of time to spend with family & 3.75 & 3.75 & 3.86 & 0.06 \\
\hline Time not available when greatest need arises & 3.73 & 3.69 & 4.14 & 1.10 \\
\hline $\begin{array}{l}\text { Relationships with students that could become } \\
\text { public relations problems }\end{array}$ & 3.45 & 3.45 & 3.42 & 0.00 \\
\hline Lack of time to supervise students & 3.42 & 3.43 & 3.29 & 0.10 \\
\hline Lack of time to devote to FFA Activities & 3.42 & 3.47 & 3.00 & 0.80 \\
\hline Lack of time to teach Young/Adult Farmers & 3.38 & 3.40 & 3.14 & 0.31 \\
\hline Abuse of summer (extended) employment. & 3.37 & 3.39 & 3.14 & 0.25 \\
\hline $\begin{array}{l}\text { Emergencies must be handled regardless of } \\
\text { school commitments. }\end{array}$ & 3.36 & 3.39 & 3.14 & 0.22 \\
\hline Hinders lesson planning & 3.35 & 3.34 & 3.43 & 0.04 \\
\hline
\end{tabular}


Table 9 (Continued)

\begin{tabular}{|c|c|c|c|c|}
\hline \multirow[t]{3}{*}{ Problems } & \multirow{3}{*}{$\begin{array}{c}\begin{array}{c}\text { Overall } \\
\text { Mean }\end{array} \\
\underline{N}=68\end{array}$} & \multicolumn{2}{|c|}{ Involvement } & \multirow[t]{3}{*}{ F-Value } \\
\hline & & No & Yes & \\
\hline & & $\underline{N}=61$ & $\underline{N}=7$ & \\
\hline $\begin{array}{l}\text { Lack of time to attend in service/professional } \\
\text { activities }\end{array}$ & 3.29 & 3.33 & 3.00 & 0.44 \\
\hline $\begin{array}{l}\text { Alienation if teachers operate competing } \\
\text { agribusiness }\end{array}$ & 3.25 & 3.21 & 3.57 & 0.52 \\
\hline Difficult to serve two masters. & 3.25 & 3.26 & 3.14 & 0.07 \\
\hline $\begin{array}{l}\text { Concern about time spent away from official } \\
\text { duties. }\end{array}$ & 3.25 & 3.25 & 3.29 & 0.01 \\
\hline $\begin{array}{l}\text { Less contact with other staff and students in the } \\
\text { school system. }\end{array}$ & 3.21 & 3.17 & 3.57 & 0.64 \\
\hline $\begin{array}{l}\text { Teacher not willing to provide community and } \\
\text { industry services. }\end{array}$ & 3.13 & 3.13 & 3.14 & 0.00 \\
\hline Lack of time for advisory committee meetings & 3.11 & 3.10 & 3.14 & 0.01 \\
\hline Prevents doing both jobs well & 3.10 & 3.11 & 3.00 & 0.47 \\
\hline Causes teaching to become part-time employment & 3.09 & 3.07 & 3.29 & 0.17 \\
\hline Encourages part-time agriculture programs. & 3.06 & 3.12 & 2.57 & 1.00 \\
\hline Working for the school or themselves questions. & 3.06 & 3.05 & 3.14 & 0.03 \\
\hline $\begin{array}{l}\text { Reduced teaching contracts for all agricultural } \\
\text { education teachers. }\end{array}$ & 3.06 & 3.03 & 3.29 & 0.22 \\
\hline Competition with others seeking employment. & 3.00 & 3.03 & 2.71 & 0.54 \\
\hline Public image problem-double dipping & 2.97 & 2.97 & 3.00 & 0.00 \\
\hline Conflict of interest—hiring students, & 2.96 & 2.93 & 3.14 & 0.15 \\
\hline Cause relationship problems with school officials & 2.93 & 2.90 & 3.14 & 0.24 \\
\hline $\begin{array}{l}\text { School administrators recognize programs as part- } \\
\text { time. }\end{array}$ & 2.92 & 2.90 & 3.14 & 0.25 \\
\hline $\begin{array}{l}\text { Image of agricultural education teaching less } \\
\text { important than other teaching areas. }\end{array}$ & 2.91 & 2.89 & 3.14 & 0.21 \\
\hline Administrators question if SAE visits are real. & 2.91 & 2.90 & 3.00 & 0.04 \\
\hline $\begin{array}{l}\text { Causes a halt in FFA activities during the } \\
\text { summer. }\end{array}$ & 2.90 & 2.90 & 2.86 & 0.01 \\
\hline $\begin{array}{l}\text { Demonstrates that teaching is not a full time } \\
\text { commitment. }\end{array}$ & 2.81 & 2.80 & 3.00 & 0.12 \\
\hline Decline in the dedication to teaching & 2.78 & 2.79 & 2.71 & 0.08 \\
\hline
\end{tabular}


Table 9 (Continued)

\begin{tabular}{llccc}
\hline \multicolumn{1}{c}{ Problems } & $\begin{array}{c}\text { Overall } \\
\text { Mean }\end{array}$ & \multicolumn{2}{c}{ Involvement } & \multicolumn{2}{c}{ F-Value } \\
\cline { 3 - 5 } & N=68 & No & Yes \\
& & $\underline{N}=61$ & $\underline{N}=7$ & \\
\hline Decreased importance of agriculture education & 2.76 & 2.77 & 2.71 & 0.01 \\
Poor community involvement by teacher. & 2.73 & 2.77 & 2.42 & 0.46 \\
Teacher loses broader perspective of agriculture. & 2.61 & 2.55 & 3.14 & 1.63 \\
Tarnishes the professional image of agriculture & & & & \\
teachers. & 2.53 & 2.52 & 2.57 & 0.01 \\
Results in a poor instructional program & 2.52 & 2.47 & 3.00 & 1.19 \\
Teachers teach content of part-time employment & 2.21 & 2.16 & 2.57 & 1.11 \\
\hline
\end{tabular}

*F-value significant at .05

$* * \mathrm{~F}$-value significant at .01

Rating scale: 1-Strongly disagree, 2-Disagree, 3-No effect, 4-Agree, 5-Strongly agree

Comparisons of Perceived Benefits and Problems of the Agricultural Education Program which

$\underline{\text { Result from the Teacher's Part-time Employment, According to Teaching Experience }}$

Analyses of variance were used to determine if differences existed between the perceptions of benefits and problems to agricultural education programs relative to their years of teaching experience. There were no significant differences between the years of teaching experience and respondents rating of benefits and problems of part-time employment (Tables 10 and 11) 
Table 10

Perceived Benefits of the Agricultural Education Program which Result from the Teacher's Part-time Employment, According to

Years of Teaching Experience

\begin{tabular}{|c|c|c|c|c|c|c|c|c|c|}
\hline Benefit & $\begin{array}{l}\text { Total } \\
\underline{N}=68\end{array}$ & $\begin{array}{c}<1 \text { year } \\
\underline{N}=4\end{array}$ & $\begin{array}{c}1-5 \\
N=9\end{array}$ & $\begin{array}{l}6-10 \\
\underline{N}=5\end{array}$ & $\begin{array}{l}11-15 \\
\underline{N}=10\end{array}$ & $\begin{array}{l}16-20 \\
\underline{N}=11\end{array}$ & $\begin{array}{l}21-25 \\
\underline{N}=12\end{array}$ & $\begin{array}{l}>25 y r s \\
\underline{N}=17\end{array}$ & F-value \\
\hline Teachers develop new knowledge and skills & 4.38 & 4.33 & 4.11 & 4.20 & 4.56 & 4.45 & 4.50 & 4.35 & 0.35 \\
\hline Teacher gain experience & 4.28 & 4.25 & 4.11 & 4.20 . & 4.22 & 4.45 & 4.50 & 4.18 & 0.30 \\
\hline Provides work experience & 4.22 & 4.00 & 4.00 & 4.20 & 4.00 & 4.36 & 4.50 & 4.24 & 0.67 \\
\hline Overcome financial needs-low salaries & 4.16 & 3.75 & 4.00 & 3.60 & 4.22 & 4.54 & 4.25 & 4.18 & 0.80 \\
\hline Source of instructional examples & 4.08 & 4.00 & 3.88 & 4.40 & 3.89 & 4.18 & 4.50 & 3.88 & 0.80 \\
\hline Teachers stay up-to-date & 4.01 & 4.00 & 3.33 & 3.75 & 4.22 & 4.09 & 4.42 & 4.00 & 0.93 \\
\hline Broadens outlook about agriculture & 3.97 & 3.00 & 3.78 & 3.80 & 4.22 & 4.27 & 4.41 & 3.65 & 1.82 \\
\hline Keeps teacher aware of industry problems & 3.94 & 3.33 & 3.56 & 4.00 & 4.00 & 4.27 & 4.00 & 3.94 & 0.48 \\
\hline Means to validate course content & 3.93 & 3.00 & 3.78 & 4.00 & 4.00 & 4.18 & 4.08 & 3.88 & 0.83 \\
\hline Cultivates student employment opportunities & 3.80 & 4.00 & 3.78 & 3.40 & 4.00 & 4.00 & 3.75 & 3.71 & 0.31 \\
\hline Enhances teacher confidence & 3.59 & 3.33 & 3.22 & 3.20 & 4.11 & 3.72 & 3.75 & 3.47 & 0.58 \\
\hline Helps attitude, prevents burn-out & 3.54 & 2.67 & 3.11 & 3.80 & 3.67 & 3.00 & 4.08 & 3.75 & 1.04 \\
\hline
\end{tabular}

*F-value significant at .05

**F-value significant at .01

Rating scale: 1-Strongly disagree, 2-Disagree, 3-No effect, 4-Agree, 5-Strongly agree 
Table 11

Perceived Problems of the Agricultural Education Program which Result from the Teacher's Part-time Employment According to

Years of Teaching Experience

\begin{tabular}{|c|c|c|c|c|c|c|c|c|c|}
\hline Problem & $\begin{array}{l}\text { Total } \\
\underline{\mathrm{N}}=68\end{array}$ & $\begin{array}{l}<1 \text { year } \\
\underline{\mathrm{N}}=4\end{array}$ & $\begin{array}{c}1-5 \\
\underline{N}=9\end{array}$ & $\begin{array}{l}6-10 \\
\underline{N}=5\end{array}$ & $\begin{array}{l}11-15 \\
\underline{N}=10\end{array}$ & $\begin{array}{l}16-20 \\
\underline{N}=11\end{array}$ & $\begin{array}{l}21-25 \\
\underline{N}=12\end{array}$ & $\begin{array}{l}>25 y r s \\
\underline{N}=17\end{array}$ & F-value \\
\hline Teachers must make judgement on time usage & 4.02 & 4.25 & 4.00 & 3.50 & 4.00 & 4.00 & 4.09 & 4.06 & 0.32 \\
\hline $\begin{array}{l}\text { Conflict of interest - using agricultural } \\
\text { education facilities. }\end{array}$ & 3.85 & 3.50 & 4.11 & 3.20 & 3.80 & 4.09 & 3.50 & 4.13 & 0.80 \\
\hline Can become a second full-time job & 3.78 & 4.25 & 2.89 & 3.00 & 4.00 & 4.18 & 3.91 & 3.88 & 2.11 \\
\hline Lack of time to spend with family & 3.74 & 4.00 & 3.44 & 3.00 & 3.90 & 3.82 & 3.55 & 4.00 & 0.63 \\
\hline Time not available during greatest need & 3.73 & 3.50 & 3.75 & 2.75 & 3.80 & 4.09 & 3.82 & 3.69 & 0.78 \\
\hline $\begin{array}{l}\text { Relationships with students/public relations } \\
\text { problems. }\end{array}$ & 3.44 & 3.00 & 3.88 & 3.00 & 3.00 & 3.27 & 3.67 & 3.69 & 1.04 \\
\hline Lack of time for supervision of students & 3.40 & 4.33 & 2.88 & 2.75 & 3.70 & 3.64 & 3.09 & 3.50 & 1.21 \\
\hline Lack of time to devote to FFA activities & 3.40 & 4.75 & 3.43 & 3.25 & 3.70 & 3.55 & 2.91 & 3.13 & 1.22 \\
\hline Lack of time to teach young-adult farmers & 3.37 & 4.00 & 3.44 & 3.00 & 3.33 & 3.64 & 3.18 & 3.25 & 0.37 \\
\hline Abuse of summer (extended) employment & 3.37 & 3.00 & 2.78 & 2.60 & 3.50 & 3.73 & 3.58 & 3.53 & 0.99 \\
\hline Emergencies must be handled regardless & 3.35 & 4.00 & 3.67 & 2.00 & 3.50 & 3.64 & 3.09 & 3.25 & 1.19 \\
\hline Hinders lesson planning & 3.34 & 4.50 & 3.00 & 3.00 & 3.60 & 3.64 & 3.18 & 3.06 & 1.30 \\
\hline Lack of time to attend inservice activities & 3.28 & 3.66 & 3.00 & 3.25 & 3.30 & 3.55 & 3.00 & 3.38 & 0.30 \\
\hline Difficult to serve two masters & 3.25 & 3.50 & 3.67 & 3.20 & 3.20 & 3.27 & 3.00 & 3.18 & 0.31 \\
\hline $\begin{array}{l}\text { Concern about time spent away from official } \\
\text { duties. }\end{array}$ & 3.25 & 3.25 & 3.56 & 3.20 & 2.90 & 3.45 & 3.58 & 2.94 & 0.56 \\
\hline $\begin{array}{l}\text { Alienation if teachers operate competing } \\
\text { agribusiness }\end{array}$ & 3.24 & 3.00 & 3.78 & 3.40 & 2.80 & 3.45 & 2.50 & 3.63 & 1.63 \\
\hline
\end{tabular}


Table 11 (Continued)

\begin{tabular}{|c|c|c|c|c|c|c|c|c|c|}
\hline Problem & $\begin{array}{l}\text { Total } \\
\underline{N}=68\end{array}$ & $\begin{array}{l}<1 \text { year } \\
\underline{N}=4\end{array}$ & $\begin{array}{l}1-5 \\
\underline{N}=9\end{array}$ & $\begin{array}{l}6-10 \\
\underline{N}=5\end{array}$ & $\begin{array}{l}11-15 \\
\underline{N}=10\end{array}$ & $\begin{array}{l}16-20 \\
\underline{N}=11\end{array}$ & $\begin{array}{l}21-25 \\
\underline{N}=12\end{array}$ & $\begin{array}{l}>25 y r s \\
\underline{N}=17\end{array}$ & F-value \\
\hline $\begin{array}{l}\text { Less contact with other staff and students in } \\
\text { the school system. }\end{array}$ & 3.21 & 3.33 & 3.89 & 2.60 & 2.70 & 3.55 & 3.08 & 3.18 & 1.06 \\
\hline $\begin{array}{l}\text { Teacher not willing to provide community and } \\
\text { industry services. }\end{array}$ & 3.12 & 3.00 & 3.22 & 3.00 & 2.90 & 3.18 & 3.17 & 3.19 & 0.08 \\
\hline Lack of time for advisory committee meetings & 3.09 & 4.00 & 2.89 & 2.50 & 3.10 & 3.45 & 2.91 & 3.06 & 0.61 \\
\hline Prevents doing both jobs well & 3.08 & 4.50 & 2.67 & 3.00 & 3.70 & 3.09 & 3.00 & 2.63 & 1.63 \\
\hline Causes teaching to become part-time & 3.08 & 3.75 & 3.00 & 3.00 & 3.20 & 3.36 & 2.73 & 2.94 & 0.42 \\
\hline $\begin{array}{l}\text { Reduced teaching contracts for all agriculture } \\
\text { teachers. }\end{array}$ & 3.06 & 3.67 & 3.11 & 3.40 & 2.70 & 2.91 & 2.83 & 3.30 & 0.44 \\
\hline $\begin{array}{l}\text { Encourages part-time agricultural education } \\
\text { programs }\end{array}$ & 3.03 & 4.25 & 3.56 & 2.50 & 2.70 & 3.09 & 2.55 & 3.06 & 1.22 \\
\hline Problem-working for school or for themselves & 3.03 & 3.50 & 3.33 & 3.00 & 2.30 & 3.09 & 3.33 & 2.94 & 0.80 \\
\hline Competition with others seeking employment & 3.00 & 3.25 & 3.22 & 2.80 & 2.60 & 2.91 & 3.17 & 3.06 & 0.40 \\
\hline Public image problem-double dipping & 2.96 & 2.75 & 3.11 & 3.40 & 2.50 & 3.00 & 2.92 & 3.06 & 0.33 \\
\hline Conflict of interest- employing students & 2.94 & 2.75 & 2.78 & 3.20 & 2.10 & 3.27 & 3.08 & 3.19 & 0.90 \\
\hline $\begin{array}{l}\text { School administrators recognize programs as } \\
\text { part-time }\end{array}$ & 2.92 & 3.00 & 3.67 & 3.40 & 2.22 & 3.18 & 2.82 & 2.65 & 1.46 \\
\hline $\begin{array}{l}\text { Causes relationship problems with school } \\
\text { officials }\end{array}$ & 2.91 & 3.25 & 3.00 & 2.80 & 2.80 & 2.73 & 3.08 & 2.88 & 0.15 \\
\hline Administrators question if SAE visits are real & 2.91 & 3.25 & 2.75 & 3.20 & 2.50 & 2.91 & 3.25 & 2.82 & 0.44 \\
\hline $\begin{array}{l}\text { Causes a halt in FFA activities during the } \\
\text { summer. }\end{array}$ & 2.90 & 3.50 & 3.33 & 3.00 & 2.30 & 3.36 & 2.75 & 2.65 & 1.03 \\
\hline $\begin{array}{l}\text { Image of agricultural education teaching less } \\
\text { important than other areas. }\end{array}$ & 2.88 & 4.25 & 2.56 & 2.80 & 2.40 & 3.18 & 2.75 & 2.94 & 1.07 \\
\hline
\end{tabular}


Table 11 (Continued)

\begin{tabular}{|c|c|c|c|c|c|c|c|c|c|}
\hline Problem & $\begin{array}{l}\text { Total } \\
\underline{N}=68\end{array}$ & $\begin{array}{l}<1 \text { year } \\
\underline{N}=4\end{array}$ & $\begin{array}{l}1-5 \\
\underline{N}=9\end{array}$ & $\begin{array}{l}6-10 \\
\underline{N}=5\end{array}$ & $\begin{array}{l}11-15 \\
\underline{N}=10\end{array}$ & $\begin{array}{l}16-20 \\
\underline{N}=11\end{array}$ & $\begin{array}{l}21-25 \\
\underline{N}=12\end{array}$ & $\begin{array}{l}>25 \mathrm{yrs} \\
\underline{\mathrm{N}}=17\end{array}$ & F-value \\
\hline Decline in the dedication to teaching & 2.83 & 2.75 & 2.78 & 3.00 & 3.00 & 3.09 & 2.55 & 2.75 & 0.18 \\
\hline $\begin{array}{l}\text { Demonstrates that teaching is not full time } \\
\text { commitment }\end{array}$ & 2.78 & 3.50 & 3.22 & 2.50 & 2.30 & 3.27 & 2.45 & 2.63 & 0.80 \\
\hline $\begin{array}{l}\text { Decreased importance of agriculture } \\
\text { education. }\end{array}$ & 2.74 & 2.67 & 2.56 & 3.00 & 2.50 & 3.00 & 2.42 & 3.00 & 0.43 \\
\hline Poor community involvement by teacher & 2.71 & 3.33 & 2.22 & 3.20 & 2.20 & 2.91 & 2.67 & 2.94 & 0.91 \\
\hline $\begin{array}{l}\text { Teacher loses broader perspective of } \\
\text { agriculture }\end{array}$ & 2.61 & 3.00 & 3.00 & 2.40 & 2.80 & 2.55 & 2.50 & 2.41 & 0.38 \\
\hline Results in a poor instructional program & 2.53 & 3.00 & 2.22 & 2.50 & 2.20 & 3.55 & 2.09 & 2.44 & 1.93 \\
\hline $\begin{array}{l}\text { Tarnishes the professional image of } \\
\text { agricultural education teachers }\end{array}$ & 2.53 & 3.25 & 2.56 & 2.40 & 2.60 & 2.91 & 2.50 & 2.12 & 0.72 \\
\hline $\begin{array}{l}\text { Teachers teach content of part-time } \\
\text { employment. }\end{array}$ & 2.21 & 2.25 & 2.56 & 2.40 & 2.40 & 1.82 & 1.92 & 2.29 & 0.77 \\
\hline
\end{tabular}

$* * \mathrm{~F}$-value significant at 0

Rating scale: 1-Strongly disagree, 2-Disagree, 3-No effect, 4-Agree, 5-Strongly agree 
Comparisons of Perceived Benefits/Problems of the Agricultural Education Program which $\underline{\text { Result from the Teacher's Part-time Employment, According to Length of Teacher Contract }}$

Analyses of variance were used to determine if differences existed between the perceptions of benefits and problems to the agricultural education program compared to the length of the teacher contract. Significant values were found in the following benefits: "teachers gain experience", "source of instructional examples," "keeps teacher aware of industry problems", "cultivates student employment opportunities" and "enhances teacher confidence." In each of the benefits, teachers currently working on a nine-month employment contract rated the benefits lower than their counterparts on $12,11,10$, and other teaching contractual categories.

Significant differences were found in the following problem categories: "competition with others seeking employment”, "public image problem,-double dipping”, "administrators question if SAE visits are real" and "encourages part-time agriculture programs". The teachers on nine-month contracts rated these problems significantly higher than their counterparts on 12 , 11, 10, and "other" teaching contracts (Tables 12 and 13). 
Table 12

Perceived Benefits of the Agricultural Education Program which Result from the Teacher's Part-time Employment, According to

Teacher Contract

\begin{tabular}{|c|c|c|c|c|c|c|c|}
\hline Benefits & $\begin{array}{c}\text { Overall } \\
\text { Mean } \\
\underline{N}=68\end{array}$ & $\begin{array}{c}12 \\
\text { month } \\
\underline{N}=42\end{array}$ & $\begin{array}{c}11 \\
\text { months } \\
\underline{\mathrm{N}}=11\end{array}$ & $\begin{array}{c}10 \\
\text { months } \\
\underline{\mathrm{N}}=9\end{array}$ & $\begin{array}{c}9 \\
\text { months } \\
\underline{\mathrm{N}}=3\end{array}$ & $\begin{array}{l}\text { Other } \\
\underline{N}=3\end{array}$ & F-value \\
\hline Teachers develop new knowledge and skills & 4.38 & 4.37 & 4.63 & 4.38 & 3.33 & 4.67 & 1.84 \\
\hline Teacher gain experience & 4.28 & 4.33 & 4.54 & 4.12 & 2.66 & 4.66 & $3.60 *$ \\
\hline Provides work experience & 4.22 & 4.26 & 4.18 & 4.25 & 3.33 & 4.67 & 1.45 \\
\hline Overcome financial needs-low salaries & 4.16 & 4.12 & 4.18 & 4.38 & 3.67 & 4.67 & 0.55 \\
\hline Source of instructional examples & 4.08 & 4.17 & 4.27 & 3.88 & 2.33 & 4.67 & $3.94 * *$ \\
\hline Teachers stay up-to-date & 4.01 & 4.07 & 3.81 & 4.13 & 3.00 & 4.67 & 1.04 \\
\hline Broadens outlook about agriculture & 3.97 & 3.95 & 4.18 & 4.12 & 2.67 & 4.33 & 1.83 \\
\hline Keeps teacher aware of industry problems & 3.94 & 4.09 & 3.72 & 4.13 & 2.00 & 4.00 & $3.00 *$ \\
\hline Means to validate course content & 3.93 & 3.93 & 4.09 & 4.00 & 2.67 & 4.67 & 2.39 \\
\hline Cultivates student employment opportunities & 3.80 & 3.93 & 3.72 & 4.00 & 2.00 & 3.67 & $3.19 *$ \\
\hline Enhances teacher confidence & 3.59 & 3.61 & 3.91 & 4.00 & 1.33 & 3.33 & $3.51 *$ \\
\hline Helps attitude, prevents burn-out & 3.54 & 3.55 & 3.72 & 3.63 & 2.33 & 3.67 & 0.62 \\
\hline
\end{tabular}

*F-value significant at .05

$* * \mathrm{~F}$-value significant at .01

Rating scale: 1-Strongly disagree, 2-Disagree, 3-No effect, 4-Agree, 5-Strongly agree 
Table 13

Perceived Problems of the Agricultural Education Program which Result from the Teacher's Part-time employment According to

$\underline{\text { Teaching Contract }}$

\begin{tabular}{|c|c|c|c|c|c|c|c|}
\hline Problem & $\begin{array}{c}\text { Overall } \\
\text { Mean } \\
\underline{N}=68\end{array}$ & $\begin{array}{c}12 \\
\text { month } \\
\underline{\mathrm{N}}=42\end{array}$ & $\begin{array}{c}11 \\
\text { months } \\
\underline{\mathrm{N}}=11\end{array}$ & $\begin{array}{c}10 \\
\text { months } \\
\underline{N}=9\end{array}$ & $\begin{array}{c}9 \\
\text { months } \\
\underline{\mathrm{N}}=3\end{array}$ & $\begin{array}{l}\text { Other } \\
\underline{N}=3\end{array}$ & F-value \\
\hline Teachers must make judgement on time usage & 4.01 & 4.05 & 4.10 & 3.67 & 4.50 & 4.00 & 0.61 \\
\hline Can become a second full-time job & 3.78 & 3.80 & 3.80 & 3.33 & 4.50 & 4.33 & 0.82 \\
\hline Lack of time to spend with family & 3.73 & 3.78 & 3.80 & 3.11 & 5.00 & 4.00 & 1.40 \\
\hline Time not available during greatest need & 3.73 & 3.78 & 3.80 & 3.22 & 4.50 & 4.00 & 0.81 \\
\hline $\begin{array}{l}\text { Relationships with students/public relations } \\
\text { problems. }\end{array}$ & 3.43 & 3.44 & 3.27 & 3.33 & 4.00 & 4.00 & 0.42 \\
\hline Lack of time for supervision of students & 3.39 & 3.40 & 3.70 & 3.11 & 3.00 & 3.33 & 0.36 \\
\hline Lack of time to devote to FFA activities & 3.39 & 3.41 & 3.70 & 3.22 & 3.50 & 2.67 & 0.39 \\
\hline Lack of time to teach young-adult farmers & 3.37 & 3.33 & 3.50 & 3.25 & 4.00 & 3.33 & 0.20 \\
\hline Abuse of summer (extended) employment & 3.37 & 3.48 & 2.82 & 3.22 & 4.33 & 3.33 & 1.11 \\
\hline Emergencies must be handled regardless & 3.35 & 3.41 & 2.80 & 3.33 & 4.00 & 4.00 & 0.77 \\
\hline Hinders lesson planning & 3.34 & 3.20 & 3.90 & 3.44 & 4.00 & 2.67 & 1.21 \\
\hline Lack of time to attend inservice activities & 3.28 & 3.35 & 3.30 & 3.11 & 4.00 & 2.33 & 0.67 \\
\hline Difficult to serve two masters & 3.25 & 3.24 & 2.73 & 3.44 & 4.00 & 4.00 & 1.26 \\
\hline $\begin{array}{l}\text { Concern about time spent away from official } \\
\text { duties. }\end{array}$ & 3.25 & 3.36 & 2.55 & 3.22 & 3.67 & 4.00 & 1.33 \\
\hline $\begin{array}{l}\text { Conflict of interest - using agricultural } \\
\text { education facilities. }\end{array}$ & 3.23 & 3.88 & 3.73 & 3.56 & 4.67 & 4.00 & 0.55 \\
\hline
\end{tabular}


Table 13 (Continued)

\begin{tabular}{|c|c|c|c|c|c|c|c|}
\hline Problem & $\begin{array}{c}\begin{array}{l}\text { Overall } \\
\text { Mean }\end{array} \\
\underline{N}=68\end{array}$ & $\begin{array}{c}12 \\
\text { month } \\
\underline{\mathrm{N}}=42\end{array}$ & $\begin{array}{c}11 \\
\text { months } \\
\underline{\mathrm{N}}=11\end{array}$ & $\begin{array}{c}10 \\
\text { months } \\
\underline{\mathrm{N}}=9\end{array}$ & $\begin{array}{c}9 \\
\text { months } \\
\underline{N}=3\end{array}$ & $\begin{array}{l}\text { Other } \\
\underline{N}=3\end{array}$ & F-value \\
\hline $\begin{array}{l}\text { Less contact with other staff and students in } \\
\text { the school system. }\end{array}$ & 3.21 & 3.17 & 2.82 & 3.56 & 3.33 & 4.00 & 0.73 \\
\hline $\begin{array}{l}\text { Teacher not willing to provide community and } \\
\text { industry services. }\end{array}$ & 3.12 & 3.10 & 2.73 & 3.44 & 4.00 & 3.00 & 0.80 \\
\hline Lack of time for advisory committee meetings & 3.09 & 3.13 & 3.10 & 3.11 & 3.00 & 2.67 & 0.09 \\
\hline Prevents doing both jobs well & 3.07 & 3.05 & 3.60 & 2.78 & 4.50 & 1.67 & 1.98 \\
\hline Causes teaching to become part-time & 3.07 & 3.27 & 2.40 & 3.11 & 3.00 & 2.67 & 0.95 \\
\hline $\begin{array}{l}\text { Reduced teaching contracts for all agriculture } \\
\text { teachers. }\end{array}$ & 3.06 & 3.10 & 2.18 & 3.44 & 4.33 & 3.33 & 2.35 \\
\hline $\begin{array}{l}\text { Alienation if teachers operate competing } \\
\text { agribusiness }\end{array}$ & 3.03 & 3.36 & 3.00 & 3.00 & 3.33 & 3.00 & 0.29 \\
\hline Problem-working for school or for themselves & 3.02 & 3.07 & 2.45 & 2.78 & 4.67 & 4.00 & 2.25 \\
\hline Competition with others seeking employment & 3.00 & 3.07 & 2.27 & 2.89 & 4.33 & 4.00 & $3.24 *$ \\
\hline Public image problem-double dipping & 2.95 & 3.07 & 2.64 & 2.11 & 5.00 & 3.00 & $3.47 *$ \\
\hline Conflict of interest- employing students & 2.94 & 2.67 & 3.00 & 3.44 & 5.00 & 3.00 & 2.67 \\
\hline $\begin{array}{l}\text { School administrators recognize programs as } \\
\text { part-time }\end{array}$ & 2.92 & 3.05 & 2.18 & 3.00 & 4.00 & 2.67 & 1.81 \\
\hline $\begin{array}{l}\text { Causes relationship problems with school } \\
\text { officials }\end{array}$ & 2.91 & 2.98 & 2.45 & 2.89 & 4.00 & 2.50 & 1.06 \\
\hline Administrators question if SAE visits are real & 2.91 & 2.95 & 2.00 & 3.22 & 4.33 & 3.33 & $3.05 *$ \\
\hline $\begin{array}{l}\text { Causes a halt in FFA activities during the } \\
\text { summer. }\end{array}$ & 2.90 & 3.02 & 2.27 & 3.11 & 4.00 & 1.67 & 2.12 \\
\hline
\end{tabular}


Table 13 (Continued)

\begin{tabular}{|c|c|c|c|c|c|c|c|}
\hline Problem & $\begin{array}{c}\text { Overall } \\
\text { Mean } \\
\underline{N}=68\end{array}$ & $\begin{array}{c}12 \\
\text { month } \\
\underline{N}=42\end{array}$ & $\begin{array}{c}11 \\
\text { months } \\
\underline{\mathrm{N}}=11\end{array}$ & $\begin{array}{c}10 \\
\text { months } \\
\underline{N}=9\end{array}$ & $\begin{array}{c}9 \\
\text { months } \\
\underline{\mathrm{N}}=3\end{array}$ & $\begin{array}{l}\text { Other } \\
\underline{N}=3\end{array}$ & F-value \\
\hline $\begin{array}{l}\text { Image of agricultural education teaching less } \\
\text { important than other areas. }\end{array}$ & 2.88 & 2.90 & 2.09 & 3.56 & 4.00 & 2.00 & 2.32 \\
\hline Decline in the dedication to teaching & 2.83 & 2.93 & 2.30 & 3.00 & 4.50 & 1.67 & 1.85 \\
\hline $\begin{array}{l}\text { Demonstrates that teaching is not full time } \\
\text { commitment }\end{array}$ & 2.78 & 2.83 & 2.40 & 3.22 & 3.50 & 1.67 & 0.92 \\
\hline $\begin{array}{l}\text { Encourages part-time agricultural education } \\
\text { programs }\end{array}$ & 2.76 & 3.24 & 2.10 & 3.33 & 4.00 & 1.67 & $2.85^{*}$ \\
\hline $\begin{array}{l}\text { Decreased importance of agriculture } \\
\text { education. }\end{array}$ & 2.74 & 2.71 & 2.64 & 3.00 & 3.33 & 2.00 & 0.45 \\
\hline Poor community involvement by teacher & 2.71 & 2.76 & 2.45 & 2.56 & 3.33 & 3.00 & 0.37 \\
\hline $\begin{array}{l}\text { Teacher loses broader perspective of } \\
\text { agriculture }\end{array}$ & 2.61 & 2.56 & 2.45 & 3.00 & 3.33 & 2.00 & 0.80 \\
\hline Results in a poor instructional program & 2.53 & 2.53 & 2.50 & 2.78 & 3.00 & 1.67 & 0.52 \\
\hline $\begin{array}{l}\text { Tarnishes the professional image of } \\
\text { agricultural education teachers }\end{array}$ & 2.53 & 2.45 & 2.36 & 3.33 & 2.67 & 1.67 & 1.48 \\
\hline $\begin{array}{l}\text { Teachers teach content of part-time } \\
\text { employment. }\end{array}$ & 2.21 & 2.24 & 1.91 & 2.67 & 2.00 & 1.67 & 1.04 \\
\hline
\end{tabular}

*F-value significant at .05

**F-value significant at .01

Rating scale: 1-Strongly disagree, 2-Disagree, 3-No effect, 4-Agree, 5-Strongly agree 


\section{$\underline{\text { Summary of Research Findings }}$}

The research was designed to determine specific demographic information about the respondents. The responses revealed that the group studied were predominately male, with nearly $75 \%$ of the respondents having 10 or more years of teaching experience. Over $50 \%$ were engaged in part-time farming, had at least a 12-month contract, and were over 40 years old. In addition to the demographic data, the teachers responding rated benefits and problems associated with part-time employment. The respondents who were involved in multiple jobholding were more likely to rate the benefits higher than those not engaged in part-time employment. These same teachers rated the problems associated with part-time employment lower than their counterparts who did not engage in moonlighting. 


\section{CHAPTER V}

\section{SUMMARY, CONCLUSIONS, AND RECOMMENDATIONS}

\section{Summary}

The purpose of this study was to determine the perceptions of high school agricultural educators as it relates to the benefits and problems associated with part-time employment. The participants in the study were those teachers employed during the 2000-2001 school year within a 150-mile radius of Ripley, West Virginia. The accessible population was 108 secondary agricultural education teachers; 35 from West Virginia, 34 from Kentucky, and 38 from Ohio.

The importance of secondary agriculture educators staying current has been stressed as an essential part of secondary agriculture since its formation. Teachers who do not stay current with new trends and technologies in agriculture will be doomed to teach only agriculture history (Harper, 1991).

The primary objective of the research was to determine how West Virginia, Kentucky, and Ohio agricultural educators employed within a 150 mile radius of the Ripley, WV area perceive the benefits and problems of part-time farming, agribusiness, and/or other employment endeavors have on professional job performances.

Secondary objectives include:

1. Identify the number of agricultural educators engaged in part-time farming, agribusiness, and/or other employment endeavors in West Virginia, Ohio, and Kentucky.

2. Determine the extent to which agricultural teachers supplement their income by means of part-time farming, agribusiness, and/or other employment enterprises.

3. Ascertain the degree to which part-time employment impacts an agriculture teacher's personal life. 
4. Determine the influences on various components of the teacher's job as perceived by those same instructors when the teacher is employed in part-time farming, agribusiness, and/or other employment pursuits.

The survey instrument was an adaptation of a questionnaire developed by Harper (1991) which included 22 benefits and 42 problems identified by state supervisors and head teacher educators in agricultural education. Part two of the survey consisted of demographic variables such as age, gender, and other information. Characteristics of early and late respondents were compared and no significant differences were found between groups.

\section{Summary of Findings}

Characteristics of the groups were as follows: Over $92 \%$ of the respondents were male, while nearly $8 \%$ were female. There were $54.4 \%$ of the respondents over the age of 40 with a surprising $7.4 \%$ of the respondents still teaching after the age of 65 . Nearly $74 \%$ of those

surveyed had over 10 years teaching experience while $25 \%$ had taught over 25 years. Fifty-nine percent of the respondents were engaged in part-time employment activities. Of those 59\% who moonlighted, almost half reported the part-time employment accounted less than 1-10\% of their gross income (46.3\%). There were 17\% involved in part-time employment earning 11-25\% of their gross income, while $22 \%$ were earning at least $25-50 \%$ of their income from other employment endeavors. Less than forty percent of the respondents had a contract less than 12 months. There were $4.4 \%$ employed on a 9-month contract. Forty-eight percent of the respondents were employed in a one-teacher department.

The findings were predictable in that teachers who were involved in multiple jobholding, especially in part-time production agriculture, were more likely to rate the benefits higher than their counterparts who were not engaged in part-time employment. Not surprisingly, the 
teachers who were involved in part-time production agriculture were more likely to rate the problems associated with multiple job holding lower than their counterparts who did not engage in part-time employment.

Participants were invited to comment on their perceptions and they offered some very interesting "food for thought." Some of the comments praised the beneficial aspects such as:

- I feel your best agricultural programs are run by teachers who are involved in agriculture. Teachers who are working in the field that they are teaching will have more respect from students and people in the community than teachers using only a textbook.

- My farm has no effect on my job performance. Agriculture is a dynamic industry, if you don't stay current, you get left behind!

- My farm has provided a good source of information and practical education opportunities for my students and myself. This information has enhanced my instruction in the classroom.

- Teachers having hands on experience is as important as students having supervised experience programs.

Others were guarded in their beliefs that conflict of interest issues can and do arise. For instance:

- Any teacher whether in agriculture or another field must always be aware of the possibility of a conflict of interest. A teacher has to make sure he/she stays within the guidelines of his/her job. If anything takes a second seat, it should be the "secondary employment."

- The answers to some of the questions listed depends on the individual agriculture teacher and the type of part-time employment. I have seen such situations be beneficial in some 
cases; and a hindrance in others. Nevertheless, an agricultural education teacher's main focus and responsibility should be being an agricultural science teacher/FFA advisor.

- Many of the questions have broader perspectives involved than can be answered. I believe teachers can abuse the primary responsibilities with outside employment. I also believe that teachers can and should be allowed to do both and they can be done successfully.

\section{$\underline{\text { Conclusions }}$}

Based upon the results of this study, the following conclusions were drawn:

1. Over half of teachers of high school agriculture were engaged in part-time employment.

2. Teachers engaged in part-time employment in production agriculture rated the benefits of the multiple job holding higher than those not engaged in production agriculture.

3. Nearly half of the agriculture teachers who moonlight receive a modest compensation for their effort (1-10\% of gross income).

4. Over half of agriculture teachers were over the age of 40 with some still teaching after the age of 65 .

5. Over half of agriculture teachers agree or strongly agree on the problems associated with "lack of time" (to spend with family, to devote to FFA activities, to supervise students, and to teach young/adult farmer classes).

6. Significant numbers (over 75\%) reported perception of conflict of interest issues (using agricultural education facilities and part-time employment can become a second full-time job).

7. Only about $60 \%$ of agricultural education teachers had a 12 -month contract. 


\section{$\underline{\text { Implications }}$}

The review of literature and the results of the study yielded support for the idea that there are important benefits to those who moonlight and teach agricultural education. However, there are negative connotations associated with those who engage in multiple job holding. Positive public relations are important for the success of any program. There is a stigma attached to these activities that may be difficult to overcome. Even when the school systems do not hire teachers of agriculture to teach for 12 months, do they have a right to make the teacher feel less professional when he or she attempts to supplement their income with part-time employment? Furthermore, if they do engage in part-time employment, what will these teachers have to sacrifice in terms of personal time, public perception, or success of their agriculture programs?

\section{$\underline{\text { Recommendations }}$}

Based on the results of this investigation the following recommendations are proposed by the researcher:

1. Further research should be conducted to determine how school administrators perceive the benefits and problems associated with part-time employment by agricultural educators.

2. Agricultural educators who are engaged in part-time employment need to be made aware of the conflict of interest issues that can arise and take care to make sure their programs do not suffer because of their involvement.

3. Teaching contracts should be lengthened to include 12-month employment for every teacher of agriculture education so that student programs will be monitored year round and FFA programs will not suffer. 
4. As the average age of agriculture teachers is increasing, there will be more need for new teachers to replace those who retire. Recruitment by teacher educators at Universities needs to be emphasized to be able to meet these future needs. As one teacher (who was called out of retirement to teach) noted in the comments: "Vo-Ag" teaching is an asset to the community, we need help to keep the programs in progress. Many school systems are dropping this program and the result will weaken United States Agriculture.

5. Educational experience compensatory incentives need to be provided to teachers involved in part-time employment such as continuing education requirements are mandatory for all teachers. As one teacher noted when asked about his views on part-time farming in particular, he stated "Part-time farming is very expensive and time-consuming inservice" 


\section{REFERENCES}

Alley, R., \& Ballenger, M. (1990 August). Moonlighting teachers leave reform efforts in the dark. School Administrator, 47(7), 20-23.

Ary, D.,Jacob, L.C., \& Razavieh, A. (1996). Introduction to research in education, fifth edition. Ft. Worth: Holt, Rinehart and Winston, Inc.

Ballou, D. (1995, April). Causes and consequences of teacher moonlighting. Education Economics, 3(1), 3-18.

Bell, D. \& Roach, P.B. (1988, August). Moonlighting-Arkansas style. Paper presented at the Association of Teacher Educators Summer Workshop.

Betts, S. C. (2000, November). An exploration of multiple jobholding (moonlighting) and $\underline{\text { an investigation into the relationship between multiple jobholding and work related commitment. }}$ Unpublished doctoral dissertation, Rutgers University, Newark, NJ.

Bobbitt, S.A. (1988). Moonlighting Among Public School Teachers. Washington, DC: National Center for Educational Statistics.

Bobbitt, S.A. (1990, April). Moonlighting among public and private school teachers. Paper presentation to the American Educational Research Association.

Boyer, E. L. (1983) High school: A report on secondary education in America. New York: Harper \& Row.

Carroll, D. L. (1994, June). Moonlighting professionals: A study of full-time teachers and their part-time work. Educational Research Quarterly; 17(4), 25-36.

Daly, P. A. (1981, November). Agricultural employment: Has the decline ended? Monthly Labor Review; 104(11), 11-17. 
Dillman, D. (1978). Mail and telephone surveys: The total design method. New York, NY: John Wiley and Sons.

Glickman, D. (1997). Census of agriculture. Washington, D.C: USDA National Agricultural Statistics Service.

Graham, J. (1988, January). Teaching farming, learning farming. Cooperative Farmer, $16-17$.

Harper, R. (1991). Benefits and problems of part-time agriculture employment of secondary agriculture teachers on their programs. Unpublished master's thesis, West Virginia University, Morgantown, West Virginia.

Henderson, D. L. \& Schlesinger, F. J . (1988). Texas teachers and moonlighting in the 1980's. Huntsville, Texas, Sam Houston State University, College of Education. (ERIC Document Reproduction Service no. ED 298 106.)

Kaplin, P.S. (1991). A child's odyssey, $2^{\text {nd }}$ edition. St. Paul, MN: West Publishing Co. Ladestro, D. (1990, August). Making ends meet. Teacher Magazine, 1(10), 54-55. Merriam-Webster. (1999). Webster's new collegiate dictionary. Springfield, MA: G. \& C. Merriam Co.

Phipps, L. G. \& Osborne, E. W. (1988). Handbook on agricultural education in public schools. Danville, IL: The Interstate Printers \& Publishers, Inc.

Pearson, L. C. (1994, May-June) Analysis of demographic, perceptual, and work-related factors in teacher moonlighting. Journal of Educational Research; 87(5), 304-308.

Raffel, J.A. \& Groff, L.R. (1990). Shedding light on the dark side of teacher moonlighting. Educational Evaluation and Policy Analysis, 12, 403-414. 
Smith, S. M. (1950, May). Can you farm and teach? The Agricultural Education Magazine, 22(11), 254,257.

U.S. Department of Labor, Bureau of Labor Statistics. (1999). Labor force statistics from the current population. Washington, DC: US Government Printing Office.

U.S. Department of Labor, Bureau of Labor Statistics. (1984). Employment and wages, annual averages 1984. Washington, DC: US Government Printing Office.

VanDalen, B. D. (1979). Understanding educational research, An introduction, (4 ${ }^{\text {th }}$ edition). New York: McGraw-Hill.

Whitener, L. A. \& Bokemeier, J. L. (1992). Moonlighting in rural America. Rural Development Perspective; 8(1), 27-31. 
APPENDICES 


\section{APPENDIX A}

Cover Letter to Secondary Agricultural Teachers 


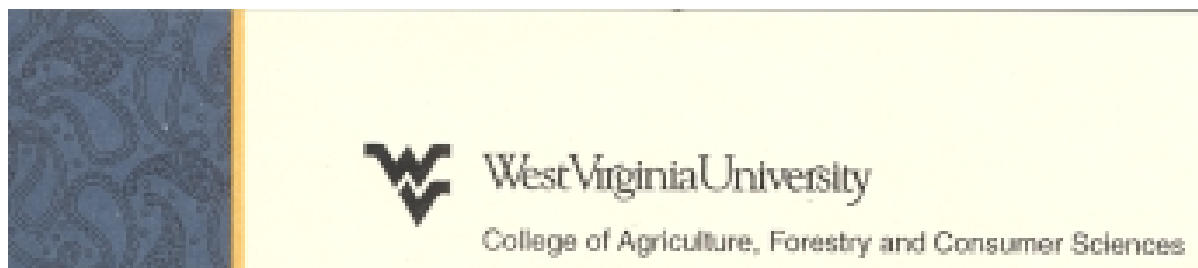

January 18,2001

Dear Agriculture Science Teachers:

There are many benefits, as well as problems, for teachers of Agriculture Education involved in part-time employment. For example, a teacher will benefit from the experience, knowledge, and skills acquired as a result of a part-time famming or agribusiness venture. On the other hand, part-time employment has the potential to create time management issues that could affect SAE supervision and participation in FFA activities.

I am conducting a self-funded study to determine the level of importance teachers in West Virginia, Ohio, and Kentucky place on selected benefits and problems associated with parttime employment as they relate to high school agriculture programs and the career of the teachers involved. Your opinions are vital to the usefulness of this study. The results of the study will be used to prepare a thesis that will complete my Masters Degree Program at West Virginia University in Agricultural and Environmental Education.

Although time is of the essence, especially this time of year, please take a few minutes to complete the enclosed questionnaire. After you complete the questionnaire, you may offer comments that will also prove helpful in the study. Be assured that all information will be held completely confidential. Your participation is voluntary and, of course, should you choose to leave a guestion blank, feel free to do so.

Please complete the enclosed questionnaire and return it to me by February lst. For your convenience, a stamped, self-addressed envelope is enclosed

Thank you in advance for your cooperation

Sincerely,

Conarie M. Ecarbrough

Agriculture Science Teacher

Ripley High School
Harry N. Boone, Jr

Assistant Professor

Agricultural and Environmental Education

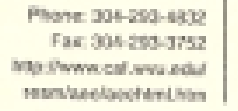

(Dis

Divisian af Aesource Management

คо вов бісе

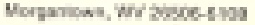


APPENDIX B

Survey Instrument 


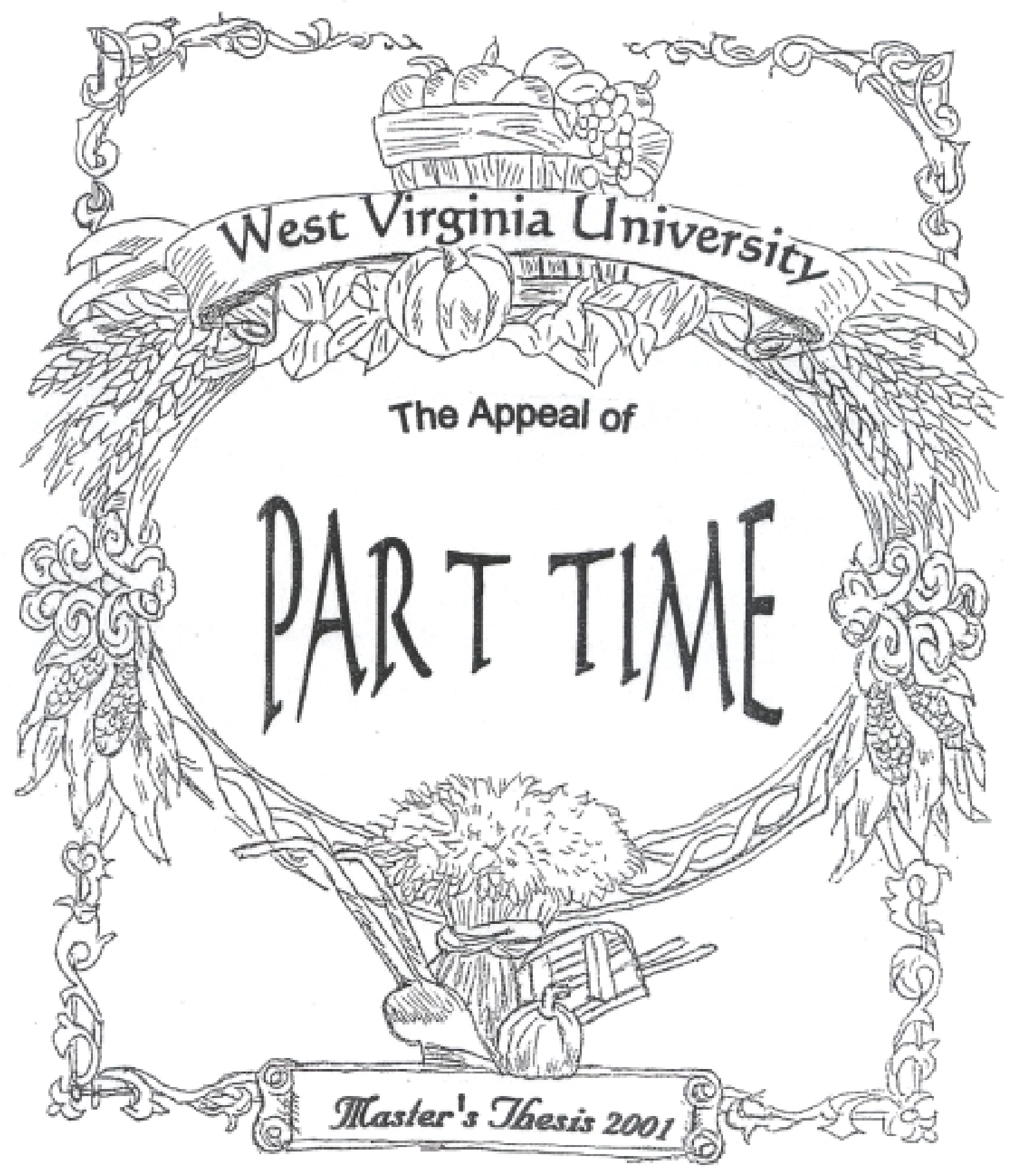


Thank you for choosing to complete this questionnaire. $R$ ate the statements according to your beliefs concerning part- time employment by teachers of agriculture education. C ircle the degree to which you agree of disagree to the statements in each category. A Iso, please complete the background information at the end of the survey instrument.

When finished, place in the return envelope and send back to my address.

P lease turn the page. 
BENEFITS

Tell to what degree you agree or disagree with the following statements about part-time employment on an agriculture educator's job performance.

Part-time employment:

Enhances confidence in teacher on part of day students /adult class members.

Cultivates employment opportunities for the students.

Allows teachers an opportunity to gain experience in agriculture industry.

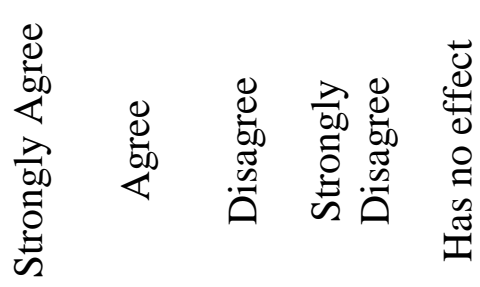

Allows teachers the opportunity to develop new knowledge and skills.

Causes teachers to stay up-to-date in the field of agriculture.

\section{TEACHING ENHANCEMENT}

Provides a source of concrete examples; keeps instruction relevant.

Provides work experience which could be helpful in teaching new skills.

Provides a means for teachers to validate the content of their courses.

Makes teachers more aware of agriculture industry problems.

Helps keeps the teacher aware of personnel hiring, problems, and needs.

Helps keep the teacher familiar with government programs and regulations.

Enhances the development of better management skills/business techniques.

Causes the teacher to be better able to stay current with language of profession.

Causes the teacher to realize the expectations some employers would have for employees entering agricultural occupations.

Helps the teacher apply "theory" into practice.

$\begin{array}{lllll}1 & 2 & 3 & 4 & 5\end{array}$

$\begin{array}{lllll}1 & 2 & 3 & 4 & 5\end{array}$

$\begin{array}{lllll}1 & 2 & 3 & 4 & 5\end{array}$

$\begin{array}{lllll}1 & 2 & 3 & 4 & 5\end{array}$

$\begin{array}{lllll}1 & 2 & 3 & 4 & 5\end{array}$

$\begin{array}{lllll}1 & 2 & 3 & 4 & 5\end{array}$

$\begin{array}{lllll}1 & 2 & 3 & 4 & 5\end{array}$

$\begin{array}{lllll}1 & 2 & 3 & 4 & 5\end{array}$

$\begin{array}{lllll}1 & 2 & 3 & 4 & 5\end{array}$

$\begin{array}{lllll}1 & 2 & 3 & 4 & 5\end{array}$

$\begin{array}{lllll}1 & 2 & 3 & 4 & 5\end{array}$

$\begin{array}{lllll}1 & 2 & 3 & 4 & 5\end{array}$

$\begin{array}{lllll}1 & 2 & 3 & 4 & 5\end{array}$

$\begin{array}{lllll}1 & 2 & 3 & 4 & 5\end{array}$

$\begin{array}{lllll}1 & 2 & 3 & 4 & 5\end{array}$ 


\begin{tabular}{|c|c|c|c|c|c|}
\hline $\begin{array}{l}\text { BENEFITS } \\
\text { Tell to what degree you agree or disagree with the following } \\
\text { statements about part-time employment on an agriculture } \\
\text { educator's job performance. } \\
\text { Part-time employment: }\end{array}$ & 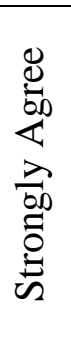 & 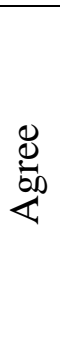 & 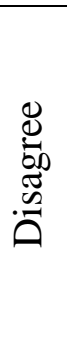 & 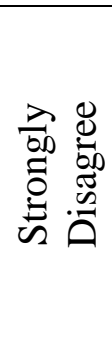 & 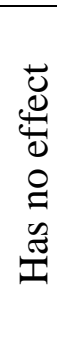 \\
\hline \multicolumn{6}{|l|}{ FARM BUSINESS FOR LAB OR FIELD TRIP } \\
\hline $\begin{array}{l}\text { Allows the teacher to use own business for field trips and student } \\
\text { SAE's. }\end{array}$ & 1 & 2 & 3 & 4 & 5 \\
\hline Can provide access to farm as a laboratory. & 1 & 2 & 3 & 4 & 5 \\
\hline \multicolumn{6}{|l|}{ PERSONAL AND FINANCIAL } \\
\hline Can lead to personal satisfaction. & 1 & 2 & 3 & 4 & 5 \\
\hline $\begin{array}{l}\text { Provides a supplemental income to allow teachers to stay in the } \\
\text { profession (particularly programs with less than } 12 \text { month } \\
\text { employment). }\end{array}$ & 1 & 2 & 3 & 4 & 5 \\
\hline $\begin{array}{l}\text { Helps overcome the financial needs caused by low teacher } \\
\text { salaries. }\end{array}$ & 1 & 2 & 3 & 4 & 5 \\
\hline Helps attitude, prevents burnout, and relieves stress. & 1 & 2 & 3 & 4 & 5 \\
\hline Broadens own outlook about agriculture. & 1 & 2 & 3 & 4 & 5 \\
\hline
\end{tabular}




\begin{tabular}{|c|c|c|c|c|c|}
\hline $\begin{array}{l}\text { PROBLEMS } \\
\text { Tell to what degree you agree or disagree with the following } \\
\text { statements about part-time employment on an agriculture } \\
\text { educator's job performance. } \\
\text { Part-time employment: }\end{array}$ & 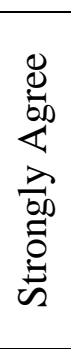 & 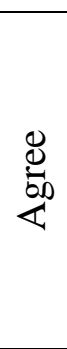 & 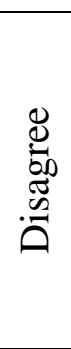 & 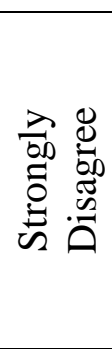 & 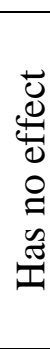 \\
\hline \multicolumn{6}{|l|}{ TIME } \\
\hline Hinders lesson planning. & 1 & 2 & 3 & 4 & 5 \\
\hline Results in a lack of time for supervision of students. & 1 & 2 & 3 & 4 & 5 \\
\hline Results in a lack of time to teach Young/Adult farmer classes. & 1 & 2 & 3 & 4 & 5 \\
\hline Results in a lack of time to devote to FFA activities. & 1 & 2 & 3 & 4 & 5 \\
\hline $\begin{array}{l}\text { Results in a lack of time to attend in-service and professional } \\
\text { development activities. }\end{array}$ & 1 & 2 & 3 & 4 & 5 \\
\hline Prevents doing both jobs well which will lead to burnout. & 1 & 2 & 3 & 4 & 5 \\
\hline Results in a lack of time to attend advisory committee meetings. & 1 & 2 & 3 & 4 & 5 \\
\hline Results in a lack of time to spend with family. & 1 & 2 & 3 & 4 & 5 \\
\hline $\begin{array}{l}\text { Does not always make time available when the greatest need } \\
\text { arises. }\end{array}$ & 1 & 2 & 3 & 4 & 5 \\
\hline $\begin{array}{l}\text { Forces teachers to make priority judgments-cannot be in two } \\
\text { places at the same time. }\end{array}$ & 1 & 2 & 3 & 4 & 5 \\
\hline $\begin{array}{l}\text { Results in poor instructional program because teacher will not } \\
\text { develop a community based program. } \\
\text { PART-TIME EMPLOYMENT BECOMES MAJOR FOCUS }\end{array}$ & 1 & 2 & 3 & 4 & 5 \\
\hline Can become a second full-time job. & 1 & 2 & 3 & 4 & 5 \\
\hline $\begin{array}{l}\text { Can cause teaching to become the part-time employment. } \\
\text { (Program gradually but surely dies). }\end{array}$ & 1 & 2 & 3 & 4 & 5 \\
\hline $\begin{array}{l}\text { Emergencies must be handled regardless of school } \\
\text { commitments. }\end{array}$ & 1 & 2 & 3 & 4 & 5 \\
\hline Contributes in a decline in the dedication to teaching. & 1 & 2 & 3 & 4 & 5 \\
\hline $\begin{array}{l}\text { Demonstrates to the community that teaching is not a full time } \\
\text { commitment. }\end{array}$ & 1 & 2 & 3 & 4 & 5 \\
\hline $\begin{array}{l}\text { Encourages part-time agriculture programs, particularly in small } \\
\text { or budget stressed schools. } \\
\text { CONFLICT OF INTEREST }\end{array}$ & 1 & 2 & 3 & 4 & 5 \\
\hline $\begin{array}{l}\text { Can cause alienation with potential supporters if teachers operate } \\
\text { agribusinesses, which compete with others in the community. } \\
\text { Can cause conflict of interest if teachers are using agriculture } \\
\text { education facilities and students to accomplish tasks related to } \\
\text { outside employment. }\end{array}$ & 1 & 2 & 3 & 4 & 5 \\
\hline
\end{tabular}




\begin{tabular}{l}
\hline PROBLEMS \\
Tell to what degree you agree or disagree with the following \\
statements about part-time employment on an agriculture \\
educator's job performance. \\
Part-time employment:
\end{tabular}

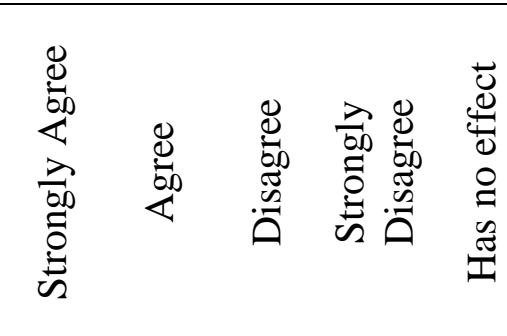
CONFLICT OF INTEREST (continued)

Can cause a conflict of interest if teachers are employing agriculture education students in part-time employment endeavors.

Can create an image that the teacher is "double dipping".

Can affect relationships with students if product sold or promoted to students causes public relations problems. Can create competition with others seeking employment.

Can cause problems in keeping the public informed as to when the teacher is working for the school board or for themselves.

\section{COMMUNITY SERVICES SUFFERS}

Results in poor community involvement by the teacher, which weakens community support.

Can result in the teacher not being willing to provide additional community and industry services.

Decreases importance of agriculture education such as the instructor's role in the community.

Can cause relationship problems with school officials.

Develops a community image of agriculture teaching as being less important than other areas of teaching with full-time instructors.

\section{PROGRAM NARROWS}

Causes teacher to lose the broader perspective of agriculture because of personal involvement.

Results in teachers teaching only to the content of part-time employment subject matter.

PROFESSIONAL IMAGE

Tarnishes the image of agriculture education teachers as professionals (Professionals don't moonlight).

May cause problems because it is difficult to serve two masters.

\section{SUMMER EMPLOYMENT}

Can result in the abuse of summer (extended) employment.

May result in reduced teaching contracts for all agriculture teachers.

\begin{tabular}{|c|c|c|c|}
\hline 1 & 2 & 3 & 4 \\
\hline 1 & 2 & 3 & 4 \\
\hline 1 & 2 & 3 & 4 \\
\hline 1 & 2 & 3 & 4 \\
\hline 1 & 2 & 3 & 4 \\
\hline 1 & 2 & 3 & 4 \\
\hline 1 & 2 & 3 & 4 \\
\hline 1 & 2 & 3 & 4 \\
\hline 1 & 2 & 3 & 4 \\
\hline 1 & 2 & 3 & 4 \\
\hline 1 & 2 & 3 & 4 \\
\hline 1 & 2 & 3 & 4 \\
\hline 1 & 2 & 3 & 4 \\
\hline 1 & 2 & 3 & 4 \\
\hline 1 & 2 & 3 & 4 \\
\hline 1 & 2 & 3 & 4 \\
\hline
\end{tabular}




\begin{tabular}{|c|c|c|c|c|c|}
\hline $\begin{array}{l}\text { PROBLEMS } \\
\text { Tell to what degree you agree or disagree with the following } \\
\text { statements about part-time employment on an agriculture } \\
\text { educator's job performance. } \\
\text { Part-time employment: }\end{array}$ & 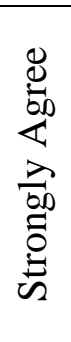 & 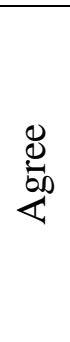 & 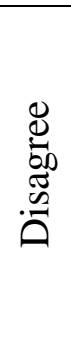 & 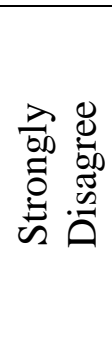 & 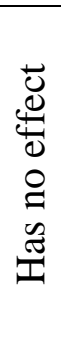 \\
\hline \multicolumn{6}{|l|}{ ADMINISTRATIVE CONCERNS } \\
\hline $\begin{array}{l}\text { Can result in less contact with other staff and students in the } \\
\text { school system }\end{array}$ & 1 & 2 & 3 & 4 & 5 \\
\hline Causes a halt in FFA activities during the summer. & 1 & 2 & 3 & 4 & 5 \\
\hline $\begin{array}{l}\text { May cause school administrators to recognize programs as only } \\
\text { part-time when teachers have other employment. }\end{array}$ & 1 & 2 & 3 & 4 & 5 \\
\hline $\begin{array}{l}\text { Administrators continually question if SAE visits are "real" or if } \\
\text { the time is being used for the business. }\end{array}$ & 1 & 2 & 3 & 4 & 5 \\
\hline $\begin{array}{l}\text { Can cause concern from school officials about time spent away } \\
\text { from official duties. }\end{array}$ & 1 & 2 & 3 & 4 & 5 \\
\hline
\end{tabular}




\section{Background Information}

Please answer the following questions. Please be assured that all information will be held completely confidential.

1. I teach agricultural education in:

Kentucky
Ohio
West Virginia

2. Years of high school agriculture teaching experience less than one

1 to 5 years 6 to 10 years 11 to 15 years 16 to 20 years

21 to 25 years more than 25 years

3. My high school agriculture teaching contract is for:

12 months

11 months

10 months

9 months

_ Other (specify)

4. Gender

Male

Female

5. Age

21 to 25 years 26 to 30 years 31 to 35 years 36 to 40 years 41 to 45 years 46 to 50 years 51 to 55 years 56 to 60 years 61 to 65 years Over 65 years 
6. Number of teachers in department

$\begin{array}{rl}1 & \\ 2 & 5 \\ 3 & -6 \text { or more }\end{array}$

7. Are you employed (including self-employment) in any endeavor other than your job as an agriculture education teacher?

_ Yes (please continue with questions 8-11)

No

For the purpose of answering questions 8-11, please assume that your agriculture science teaching position is your primary occupation and that your other employment is your secondary occupation.

8. My secondary employment involves: (Check all that apply.)

Production agriculture (farming)

Agribusiness

Non-agriculture endeavor.

Please specify

9. How many years have you been involved in this secondary employment? less than one

1 to 5 years

6 to 10 years

11 to 15 years

16 to 20 years

21 to 25 years

more than 25 years

10. What percentage of your gross income is generated through this second employment?

$0 \%$
-1 to $10 \%$
11 to $25 \%$
26 to $50 \%$
51 to $75 \%$
$76 \%$ or more

11. On an average throughout the entire year, how many hours per week do you devote to your second employment endeavor?

0 to 10 hours

11 to 20 hours

21 to 30 hours

31 to 40 hours

more than 40 hours 
Thank you so much for your part in completing the survey. Please feel free to comment in the space provided below. 
APPENDIX C

Follow-Up Post Card 


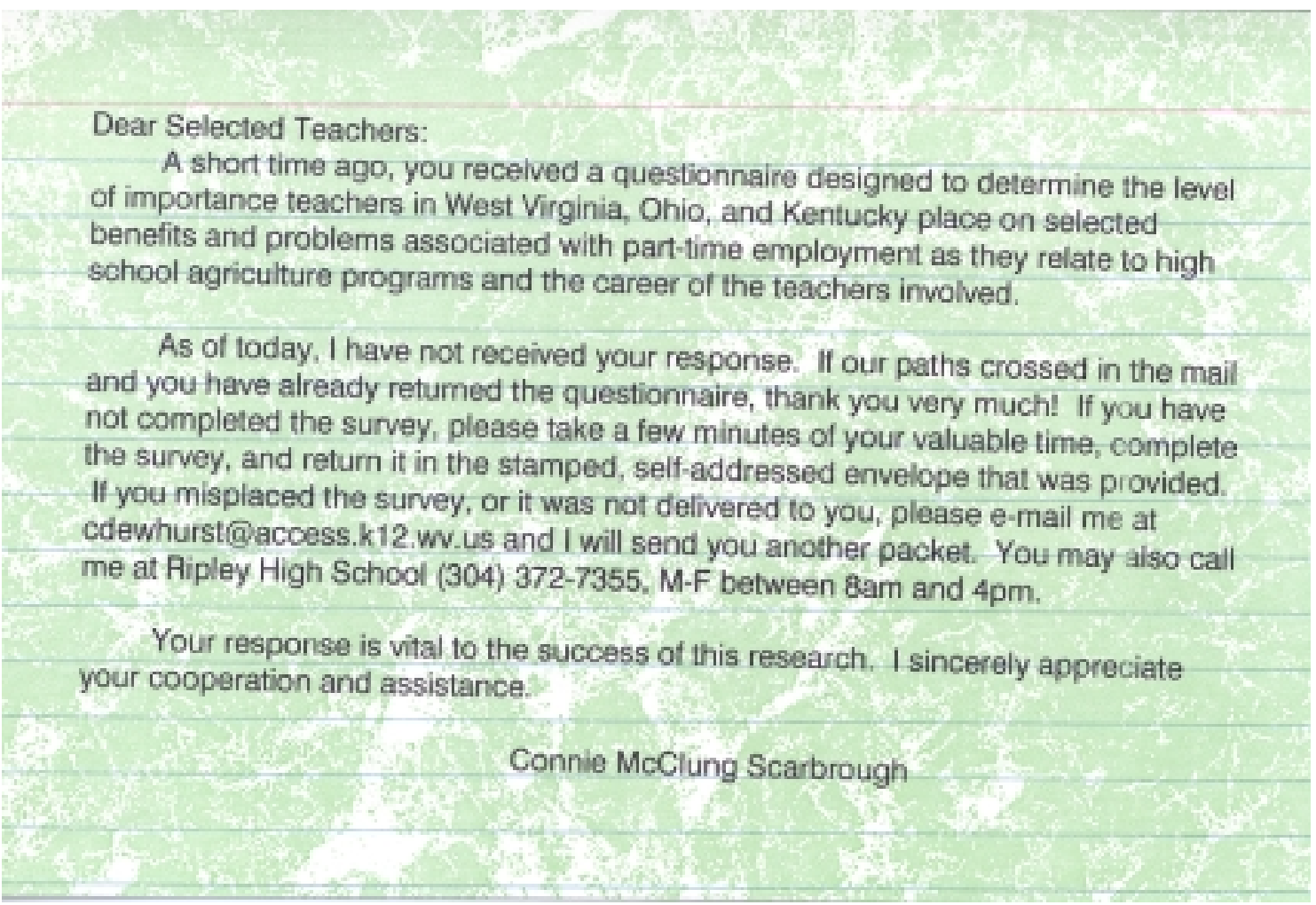


APPENDIX D

Follow-Up Letter 
February 8, 2001

Dear Selected Teachers:

A short time ago, you received a questionnaire designed to determine the level of importance teachers in West Virginia, Ohio and Kentucky place on selected benefits and problems associated with part-time employment as they relate to the high school programs and the career of the teachers involved.

As of today, I have not received your response. If our paths crossed in the mail and you have already returned the questionnaire, please take a few minutes of your valuable time, complete the survey, and return it in the stamped, self-addressed envelope. Please do not hesitate to provide this important information. The deadline for this summary is soon approaching. If you could return the survey by March 2, 2001, your response will be counted.

Your response is vital to the success of this research. I sincerely appreciate your cooperation and assistance.

Sincerely,

Connie McClung Scarbrough

Agricultural Educator

Ripley High School 
APPENDIX E

Comments 


\section{COMMENTS}

1. Opinions are a result of working with Ag. Teachers whom have one or more secondary jobs.

2. Some good thought provoking questions. It would be interesting to see what administration feel about some questions that would apply.

3. Teachers having hands on experience is as important as students having supervised experience programs.

4. Ag. Teachers with secondary jobs should keep it separate. No hiring of students, no use of school equipment or time. I feel conflict can arise when this line is crossed as private and public jobs should never influence each other. I did this for seven years and it worked out fine.

5. Remember: Confidential

6. Would spend more time with my part-time job if I did not work so far from home. This does help with community problems though since I don't compete with any of them. Nice survey.

7. I answered the questions as it has relate to the program at my school and my involvement in part time work.

8. I answered these from my own perspective: How owning a grocery store and teaching agriculture has been a partnership for me in my years of teaching-It may be different for someone in another locality. Thanks for asking and for the wonderful comments.

9. Due to the lack of part time forestry jobs it is nearly impossible to be a part time educator and forestry worker. This has influenced my answers.

10. Good luck with your research!

11. I guess work ethics is more at hand here than pros and cons-"does" and "may." Should an Ag. teacher sacrifice his personal interest, family, and happiness to the Ag. Ed. cause? No. Should an Ag. teacher give an honest day's work for an honest day's pay? Yes.

12. I took over family farm after my father passed away last March.

13. A very thorough questionnaire.

14. My farm has provided a good source of information and practical education opportunities for my students and myself. This information has enhanced my instruction in the classroom.

15. Some questions prejudice the answers by their wording. Especially questions that start with "Can..." Example: under "Summer Employment" "Can result in the abuse of summer (extended) employment." Secondary employment is unlikely to cause abuse so the answer should be disagree, "but" the "Can" suggests the possibility. It is possible? Yes! If the 
teacher allows it to! I should have answered "agree" if entirely truthful, because while I do not believe it to be a problem it is possible! Similarly, many teachers should answer "agree" even if they believe it is OK. On balance, I have found more benefits than negatives in owning and operating a farm on the side.

16. Any teacher whether in Ag. or another field must always be aware of the possibility f a conflict of interest. A teacher has to make sure he stays within the guidelines of his/her job. If anything has to take a second seat it should be the "secondary employment."

17. Although I have farmed and taught for many years, I have always tried to keep the two occupations separate. The biggest problems not fully addressed in the survey are: 1) Lack of energy after a number of 70 hour weeks. 2) Lack of pay which necessitates that a professional act in a non-professional manner in order to support his/her family in a suitable manner.

18. The answers to some of the questions listed depends on the individual Ag. Teacher and the type of part-time employment. I've seen such situations be beneficial in some cases; and a hindrance in others. Nevertheless, an Ag. teacher's main focus and responsibility should be being an agricultural science teacher/FFA advisor.

19. It is no concern of others if I farm. Ag. teachers should never be singled out for part-time employment.

20. Agriculture teachers are employed by school systems not owned by them. We are entitled to do anything with our "free" time that we choose. The character of an individual is not determined by whether or not he/she has part time employment. How many hours per week are employers entitled to beyond those for which compensation is given?

21. My farm has no effect on my job performance. Agriculture is a dynamic industry, if you don't stay current you get left behind!

22. It was difficult for me to answer the questions because teaching is my full-time job.

23. Many of the questions have broader perspectives involved than can be answered. I believe teachers can abuse the primary responsibilities with outside employment. I also believe that teachers can and should be allowed to do both and they can be done successfully. I do however realize that there can be abuse that relates to this.

24. I feel your best Ag. programs are run by teachers who are involved in agriculture. Teachers who are working in the field that they are teaching will have more respect from students and people in the community than teachers using only a textbook. 
VITA 


\section{VITA}

November 13, 1960

May 1978

May 1980

August 1984

August 1984-July 1986

July 1986-Present

May 13, 2001
Born: Hammond, Indiana

High School Graduation

Ripley High School

Ripley, West Virginia

Associate Degree

Horticulture

Potomac State College of WVU

Keyser, West Virginia

Bachelor of Science in

Agriculture Education

West Virginia University

Morgantown, West Virginia

Agricultural Education Teacher Barboursville High School

Barboursville, West Virginia

Agricultural Education Teacher

Ripley High School

Ripley, West Virginia

Master of Science in

Agriculture Education

West Virginia University

Morgantown, West Virginia

Accomplishments:

Honorary Chapter Degrees from Barboursville, Ripley, and Mason County Vocational Chapters Agriscience Teacher of the Year for West Virginia-1990

Honorary State FFA Degree - 1991

Honorary American Degree - 1994

President of the West Virginia Agriculture Educators Association - 1996

Currently serving as Vice-President 